Authors' contribution/

Wkład autorów:

A. Zaplanowanie badań/

Study design

B. Zebranie danych/

Data collection

C. Analiza statystyczna/

Statistical analysis

D. Interpretacja danych/

Data interpretation

E. Przygotowanie tekstu/

Manuscript preparation

F. Opracowanie

piśmiennictwa/

Literature search

G. Pozyskanie funduszy/

Funds collection

\section{ASSESSMENT OF INVESTMENT IN THE CAFÉ SERVICE SECTOR}

\author{
Mieczysław Adamowicz $^{1(\mathrm{~A}, \mathrm{C}, \mathrm{D}, \mathrm{E}, \mathrm{G}, \mathrm{G})}$, Karolina Ziółkowska ${ }^{2(\mathrm{~B}, \mathrm{C}, \mathrm{F})}$ \\ ${ }^{1}$ Pope John Paul II State School of Higher Education in Biała Podlaska \\ Państwowa Szkoła Wyższa im. Papieża Jana Pawła II w Białej Podlaskiej \\ ${ }^{2}$ Warsaw University of Life Sciences \\ Szkoła Główna Gospodarstwa Wiejskiego w Warszawie
}

\section{ORIGINAL ARTICLE}

JEL code: D24, L21, M21

Submitted:

October 2017

Accepted:

January 2018

Tables: 10

Figures: 0

References: 24
Adamowicz M., Ziółkowska K. (2018), Assessment of investment in the café service sector/Ocena przedsięwzięcia inwestycyjnego w sektorze usług kawiarnianych. Economic and Regional Studies, Vol. 11, No. 1, pp. 90-108. https://doi.org/10.29316/ers-seir.2018.07

\title{
Summary
}

Subject and purpose of work: The subject of the work is the issue related to making investment decisions on the Polish market of café services in Warsaw. The work contains a theoretical and an empirical part. The aim of the work is to evaluate the effectiveness of different ways of running a café in the form of creating your own brand, a network café franchise or cooperation based on an agency agreement.

Materials and methods: The work was based on the problem literature, materials made available by companies offering cooperation in the cafeteria industry and reports from a research company regarding the HoReCa market. A prospective ex-ante analysis has been given the form of a business plan for a newly created coffee shop.

Results: The basics of creating a new enterprise were discussed and the undertaking was characterized taking into account the location, competition, employment plan, marketing and risk assessment. A SWOT analysis and financial forecasts were prepared, taking into account capital expenditures, demand forecast, revenues, costs and margins, as well as the analysis of other financial parameters.

Conclusions: Available business models offer the investor a wide range of investment options. The choice of a business model depends both on the investor's expectations and its proneness to risk taking as well as on the location of the planned undertaking.

Keywords: financial analysis, café services, market entry, prospective analysis

\section{Streszczenie}

ORYGINALNY ARTYKUŁ NAUKOWY

Przedmiot i cele pracy: Przedmiotem pracy jest problematyka związana z podjęciem decyzji inwestycyjnych na polskim rynku usług kawiarnianych w Warszawie. Praca zawiera cześć teoretyczną i część empiryczną. Celem pracy jest ocena efektywności różnych sposobów prowadzenia kawiarni w Klasyfikacja JEL: D24, L21, postaci stworzenia własnej marki, franczyzy kawiarni sieciowej lub współpracy opartej na umowie M21

Zgłoszony: agencyjnej.

Materiały i metody: Praca została oparta na literaturze problemu, na materiałach udostępnionych przez firmy oferujące współpracę w branży usług kawiarnianych i raportach firmy badawczej dotyczących rynku HoReCa. Prospektywnej analizie ex-ante nadano postać biznes planu dla nowo tworzonej kawiarni.

Wyniki: Omówiono podstawy tworzenia nowego przedsiębiorstwa i scharakteryzowano Zaakceptowany: Styczeń 2018 przedsięwzięcie z uwzględnieniem lokalizacji, konkurencji, planu zatrudnienia, marketingu i oceny ryzyka. Wykonano analizę SWOT i prognozy finansowe uwzględniające nakłady inwestycyjne, prognozę popytu, wysokość przychodów, kosztów i marż oraz analizę innych parametrów finansowych.

Tabele: 10

Rysunki: 0

Literatura: 24 inwestycyjnych. Wybór modelu biznesowego zależy zarówno od oczekiwań inwestora i jego skłonności do ryzyka jak i od lokalizacji planowanego przedsięwzięcia.

Słowa kluczowe: analiza finansowa, usługi kawiarniane, wejście na rynek, analiza prospektywna

Address for correspondence/ Adres korespondencyjny: prof. zw. dr hab. Mieczysław Adamowicz (ORCID 0000-0002-1164-4966), Państwowa Szkoła Wyższa im. Papieża Jana Pawła II w Białej Podlaskiej, Wydział Nauk Ekonomicznych i Technicznych, ul. Sidorska 95/97, 21-500 Biała Podlaska, Poland; tel. +48 83 344-99-05; e-mail: adamowicz.mieczyslaw@gmail.com

Journal indexed in/ Czasopismo indeksowane w: AgEcon Search, AGRO, BazEkon, Index Copernicus Journal Master List, ICV 2016: 92,91; Polish Ministry of Science and Higher Education 2016: 9 points / AgEcon Search, AGRO, BazEkon, Index Copernicus Journal Master List ICV 2016: 92.91; Ministerstwie Nauki i Szkolnictwa Wyższego 2016: 9 punktów. Copyright: (C) 2018 Pope John Paul II State School of Higher Education in Biała Podlaska, Mieczysław Adamowicz, Karolina Ziółkowska. All articles are distributed under the terms of the Creative Commons Attribution-NonCommercial-ShareAlike 4.0 International (CC BY-NC-SA 4.0) License (http://creativecommons.org/licenses/bync-sa/4.0/), allowing third parties to copy and redistribute the material in any medium or format and to remix, transform, and build upon the material, provided the original work is properly cited and states its license. 


\section{Introduction}

The subject of the work is the assessment of the investment project and the use of a prospective financial analysis to create a small enterprise and enter the market of café services in the city of Warsaw. The analysis was carried out for economic conditions in 2015.

The work contains a theoretical part explaining the essence and content of the business plan of the enterprise, with particular emphasis on the financial analysis of the plan as well as the analytical and empirical part, in which the assessment of different options for running a café in Warsaw has been presented. The aim of the article is to assess the effectiveness of various ways of running a coffee shop using a prospective financial and organizational analysis. Three business models of running a café were subject to the creation of own brand, entering into a franchise agreement in the café chain and conclusion of an agreement on the market. The differences between the three ways of running café services, both from the financial and from the organizational and legal perspective will be presented. The work was based on the problem literature, available reports and pieces of information of specialized institutions and materials made available by companies offering franchise or cooperation in the cafeteria industry.

\section{Business plan and financial analysis as the basis for enterprise creation}

Starting a business by creating a new enterprise requires a series of pre-emptive activities (seed phase), carrying out the appointment itself (startup phase) and the process of entering the market (start-up phase) (Matusiak 2006). Going through the successive stages of the founding process and starting your own enterprise requires having personality predispositions for entrepreneurial activities, a large pool of knowledge and ingenuity regarding the intended subject of activity, the ability to use legal, economic and financial knowledge necessary to design the enterprise, prepare a business plan and access to the resources of the organizational and technical implementation of the project in force (Cieślik 2006, Dobrołowicz 2012, Kraśnicka 2002, Matusiak 2007, Mażewska 2005, Mućko and Sokół 2011, Skrzypek 2009, Wach 2005).

K.B. Matusiak lists a number of basic characteristics of entrepreneurial people that have an impact on business success such as decisiveness, consistency, flexibility, communication skills, ability to interact, creativity, initiative, perceptiveness, ability to predict the development of the situation, moderate risktaking ability and the ability to work hard. In addition to predisposition, it is also important to believe that one can succeed and consistently strive for a goal (Matusiak 2006).

W. Dobrołowicz gives a whole list of features that make it difficult and easy for entrepreneurial activities that involve the entrepreneur's mental

\section{Wstęp}

Przedmiotem pracy jest ocena przedsięwzięcia inwestycyjnego oraz wykorzystania prospektywnej analizy finansowej do stworzenia małego przedsiębiorstwa i wejścia na rynek usług kawiarnianych na terenie miasta Warszawa. Analizę przeprowadzono dla warunków ekonomicznych w 2015 roku.

Praca zawiera część teoretyczną wyjaśniającą istotę i treść biznesplanu przedsięwzięcia ze szczególnym zwróceniem uwagi na analizę finansową planu a także część analityczno-empiryczną, w której zaprezentowano ocenę różnych wariantów prowadzenia kawiarni w Warszawie. Celem artykułu jest ocena efektywności różnych sposobów prowadzenia kawiarni przy zastosowaniu prospektywnej analizy finansowej i organizacyjnej. Analizie, poddano trzy modele biznesowe prowadzenia kawiarni $\mathrm{w}$ postaci stworzenia własnej marki, wejścia w umowę franczyzową w sieci kawiarni oraz zawarcia umowy ajencyjnej. Przedstawione zostaną różnice pomiędzy trzema sposobami prowadzenia usług kawiarnianych, zarówno od strony finansowej jak i od strony organizacyjno-prawnej. Praca została oparta na literaturze problemu, dostępnych raportach i informacjach wyspecjalizowanych instytucji oraz materiałach udostępnionych przez firmy oferujące współpracę w ramach franczyzy lub ajencji w branży usług kawiarnianych.

\section{Biznes plan i analiza finansowa jako podstawa tworzenia przedsiębiorstwa}

Uruchomienie działalności gospodarczej poprzez tworzenie nowego przedsiębiorstwa wymaga szeregu działań wyprzedzających (faza zalążkowa), przeprowadzenia samego aktu powołania (faza rozruchu) i procesu wejścia na rynek (faza uruchomienia) (Matusiak 2006). Przejście przez kolejne fazy procesu założycielskiego i uruchomienia własnego przedsiębiorstwa wymaga posiadania predyspozycji osobowościowych do działań przedsiębiorczych, dużego zasobu wiedzy i pomysłowości dotyczącej zamierzonego przedmiotu działania, zdolności do wykorzystania wiedzy prawnej, ekonomicznej i finansowej niezbędnej do zaprojektowania przedsięwzięcia, sporządzenia biznesplanu oraz dostępu do zasobów organizacyjno-technicznego wdrożenia projektu w życie (Cieślik 2006, Dobrołowicz 2012, Kraśnicka 2002, Matusiak 2007, Mażewska 2005, Mućko i Sokół 2011, Skrzypek 2009, Wach 2005).

K. B. Matusiak wymienia szereg podstawowych cech osób przedsiębiorczych, które mają wpływ na sukces $\mathrm{w}$ biznesie takich jak zdecydowanie, konsekwencja, elastyczność, komunikatywność, umiejętność współdziałania, pomysłowość, inicjatywa, spostrzegawczość, zdolność przewidywania rozwoju sytuacji, umiarkowana zdolność do podejmowania ryzyka i umiejętność ciężkiej pracy. Oprócz predyspozycji ważna jest także wiara w to, że można odnieść sukces i konsekwentne dążenie do celu (Matusiak 2006).

W. Dobrołowicz wymienia całą listę cech sprzy- 
needs, motivation and ability to make decisions, approach to risk, reaction to successes and failures, attitude towards innovation, ability to overcome barriers, cooperation and creative behavior (Dobrołowicz 2012).

Theoretical foundations of enterprise creation and development come from the economics of production (industry and trade), theory of organization of the enterprise and theory of personality behavior on the labor market. Economics of industry and trade explains the company's ability to generate profit and development, the company's organization theory draws attention to the structural features, organization and compliance of its objectives with the environment, and theory of personality behavior explains various behaviors of entrepreneurs resulting from their personal qualities, knowledge and qualifications. Creating a new enterprise is a process within which two complementary aspects are distinguished (Kraśnicka 2002); subject-based, including entrepreneurial features and decisionmaking mechanisms, and organization-based, related to the construction of the company, its structure and type of legal and organizational and technical activities in a specific environment. Establishing and launching the undertaking requires the compilation of materials, production resources, staff and ensuring the funding. The founding process ends with the company's ability to generate long-term profits.

In the seed stage of the company's creation process, the idea of business matures and its concept is created, in the start-up phase, the concept enters into the implementation stage and takes on specific legal features and real organizational-technical forms. In the start-up phase of the project, it undergoes market verification, which leads to the company's development or decline. At each stage, different types of activities dominate, at the first stage the conceptual aspects, at the second stage, the decisionmaking, and at the third the organizational ones. Each stage requiresdifferent type of knowledge and competence, various activities and external support, as well as the forms and scale of funding. Creating a company is therefore a complex process with many threats and a high degree of uncertainty. The most important aspects include gathering the necessary capital resources to launch the project and provide it with stable financing. The survival and success of the company depends to a large extent on the preparation of a realistic and accurate business plan.

A business plan is a plan to conduct an investment, operation and development of a company (Matusiak 2006, Żaro, Sasin 2005, Skrzypek 2009). Thus, a business plan is an outline of intentions for the near future in which the conviction about the success or failure of a venture should be grounded. It is both a preliminary verification of the investment idea and the way it is implemented and operated over a period of several or even a dozen years. It is necessary when applying for external funds to invest in the idea and also when concluding cooperation agreements with other business entities. Having a business plan does not ensure success but makes it easier to make jających i utrudniających działania przedsiębiorcze osób, wiążących się z potrzebami psychicznymi przedsiębiorcy, jego motywacją i zdolnością do podejmowania decyzji, podejściem do ryzyka, reakcja na sukcesy i niepowodzenia, postawą wobec innowacji, zdolnością do pokonywania barier oraz współpracy i zachowań twórczych (Dobrołowicz 2012).

Podstawy teoretyczne tworzenia i rozwoju przedsiębiorstwa wywodzą się $\mathrm{z}$ ekonomiki produkcji (przemysłu i handlu), teorii organizacji przedsiębiorstwa oraz teorii zachowań osobowościowych na rynku pracy. Ekonomika przemysłu i handlu wyjaśnia zdolność firmy do generowania zysku i rozwoju, teoria organizacji przedsiębiorstwa zwraca uwagę na cechy strukturalne, organizacji i zgodności jej celów z otoczeniem, zaś teoria zachowań osobowościowych wyjaśnia różne zachowania przedsiębiorców wynikające z ich cech osobowych, wiedzy i kwalifikacji. Tworzenie nowego przedsiębiorstwa jest procesem w ramach którego wyodrębnia się dwa komplementarne aspekty (Kraśnicka 2002); podmiotowy obejmujący cechy przedsiębiorcy i mechanizmy podejmowania decyzji oraz organizacyjny-dotyczący budowy firmy, jej struktury i rodzaju działań prawnych i organizacyjno-technicznych w określonym otoczeniu. Założenie i uruchomienie przedsięwzięcia wymaga skompletowania materiałów, zasobów produkcyjnych, kadry pracowniczej oraz zapewnienia finansowania. Proces założycielski kończy się osiągnięciem zdolności firmy do generowania trwałych zysków.

W fazie zalążkowej procesu tworzenia firmy dojrzewa idea biznesu i powstaje jej koncepcja, w fazie rozruchu koncepcja przechodzi w etap realizacji i przybiera konkretne cechy prawne oraz realne formy organizacyjno-techniczne. W fazie uruchomienia przedsięwzięcia przechodzi weryfikację rynkową, która prowadzi do rozwoju lub upadku firmy. $\mathrm{Na}$ każdym etapie dominują inne rodzaje działań, w pierwszym dominują aspekty koncepcyjne, w drugim decyzyjne zaś w trzecim organizacyjne. Każdy etap wymaga innego rodzaju wiedzy i kompetencji, różnych działań i wsparcia zewnętrznego oraz form i skali finansowania. Tworzenie przedsiębiorstwa jest zatem złożonym procesem $\mathrm{z}$ wieloma zagrożeniami i dużą dozą niepewności. Do najważniejszych aspektów należy zgromadzenie niezbędnych zasobów kapitałowych do uruchomienia przedsięwzięcia i zapewnienie mu stabilnego finansowania. Przetrwanie i sukces firmy zależy w dużym stopniu od sporządzenia realnego i trafnego biznesplanu.

Biznesplan jest planem przeprowadzenia inwestycji, działania i rozwoju przedsiębiorstwa (Matusiak 2006, Żaro, Sasin 2005, Skrzypek 2009). Biznesplan jest więc zarysem zamierzeń na najbliższą przyszłość i przyszłość, w której powinno ugruntować się przekonanie o powodzeniu lub niepowodzeniu przedsięwzięcia. Stanowi on zarówno wstępną weryfikację pomysłu inwestycyjnego jak i sposobu jego wdrożenia i funkcjonowania przez okres kilku czy kilkunastu lat. Jest niezbędny przy ubieganiu się o środki zewnętrzne na inwestowanie pomysłu a także przy zawieraniu umów o współpracy z innymi podmiotami gospodarczymi. Posiadanie biznesplanu nie 
a decision about starting a business and helps to run. A well-designed business plan should be objective, purposeful, specific, flexible, useful, concise, clear and comprehensive (Matusik 2006). The structure of a standard business plan should include: a description of the undertaking, its mission and vision, SWOT analysis, technical and organizational plan, marketing plan and financial analysis. The financial analysis includes an investment plan, profit and loss forecast, profitability assessment and level of expenditure, cash flows and analysis of the project indicators.

The technical and organizational analysis, the economic and financial analysis and the analysis of the environment are of key importance for the business plan (Penc 2005, Gabrusewicz 2005, Sierpińska, Jachna 2004, Walczak 1998). In this work, particular attention will be paid to financial analysis, which is treated as a tool for assessing economic size resulting from future economic events taking place in the enterprise and planned economic events resulting from the development strategy and methods of its implementation (Gabrusewicz 2014). Financial analysis can be conducted according to various criteria, such as the purpose of the analysis (internal and external), time including the analysis (retrospective, current, prospective), applied research methods (functional, comprehensive, decisionmaking), detailed research (detailed, general) and forms of research (indicative and settlementbased). The financial analysis is performed mainly for important needs of an individual, but it is also used by creditors, potential investors and partners, financial market and financial control institutions and state agencies (tukasik 2006). The subject scope of the financial analysis consists of the analysis of revenues and expenses, analysis of the financial result and profitability, analysis of the property and financial situation, analysis of cash flows and effectiveness analysis (Gabrusewicz 2014). When planning and launching a new venture, we are dealing with a prospective (ex-ante) analysis. Prospective analysis provides the basis for making decisions relating to the future and includes cognitive and decision-making aspects. It also defines the ways of conducting and the direction of further improvement of the enterprises' operations (Bednarski 2011). The ex-ante analysis was used to assess the validity and manner of running a café services company in Warsaw (Ziółkowska 2016).

\section{The model of running café services}

Coffee is a stimulant, the consumption of which is a part of the home life, it fills work breaks and is an important part of social life. Consuming good coffee outside home is a common practice used by consumers in Poland, especially in cities. Over the past 15 years, coffee consumption in Poland has increased at a rate of $1 \%$ per year and in 2015 it reached around $3 \mathrm{~kg}$ per person per year. To a great extent, the increase in coffee consumption is related to the development zapewnia sukcesu ale ułatwia podjęcie decyzji o uruchomieniu firmy, pomaga przy jej prowadzeniu. Dobrze przygotowany plan powinien być obiektywny, celowy, konkretny, elastyczny, użyteczny, zwięzły, przejrzysty i kompleksowy (Matusik 2006). W strukturze standardowego biznesplanu powinny znaleźć się: opis przedsięwzięcia, jego misja i wizja, analiza SWOT, plan techniczno-organizacyjny, plan marketingowy i analiza finansowa. Analiza finansowa obejmuje plan inwestycyjny, prognozę zysków i strat, ocenę rentowności i poziom nakładów, przepływy pieniężne i analizę wskaźników przedsięwzięcia.

Kluczowe znaczenie dla biznesplanu ma analiza techniczno-organizacyjna, analiza ekonomiczno-finansowa i analiza otoczenia (Penc 2005, Gabrusewicz 2005, Sierpińska, Jachna 2004, Walczak 1998). W niniejszej pracy szczególna uwaga zostanie zwrócona na analizę finansową, która traktowana jest jako narzędzie służące do oceny wielkości ekonomicznych wynikających z przyszłych zdarzeń gospodarczych zachodzących w przedsiębiorstwie oraz planowanych zdarzeń gospodarczych wynikających ze strategii rozwoju i metod jej realizacji (Gabrusewicz 2014). Analizę finansowa można prowadzić według różnych kryteriów takich jak przeznaczenie analizy (wewnętrzne i zewnętrzne), czasu obejmującego analizę (retrospektywna, bieżąca, prospektywna), zastosowanych metod badawczych (funkcjonalna, kompleksowa, decyzyjna), szczegółowości badań (szczegółowa, ogólna) i formy badań (wskaźnikowa i rozliczeniowa). Analiza finansowa wykonywana jest głównie dla ważnych potrzeb jednostki, ale korzystają z niej także wierzyciele (kredytodawcy), potencjalni inwestorzy i partnerzy, instytucje ryn$\mathrm{ku}$ finansowego i kontroli finansowej oraz agendy państwowe (Łukasik 2006). Przedmiotowy zakres analizy finansowej składa się $\mathrm{z}$ analizy przychodów i kosztów, analizy wyniku finansowego i rentowności, analizy sytuacji majątkowej i finansowej, analizy przepływów pieniężnych oraz analizy efektywności (Gabrusewicz 2014). Przy planowaniu i uruchomieniu nowego przedsięwzięcia mamy do czynienia $\mathrm{z}$ analizą prospektywną (ex-ante). Analiza prospektywna dostarcza podstaw do podjęcia decyzji odnoszących się do przyszłości i obejmuje aspekty poznawcze oraz decyzyjne. Określa ona również sposoby prowadzenia oraz kierunku dalszego doskonalenia działalności przedsiębiorstw (Bednarski 2011). Analiza ex-ante została wykorzystana do oceny zasadności i sposobu prowadzenia przedsiębiorstwa usług kawiarnianych w Warszawie (Ziółkowska 2016).

\section{Model prowadzenia usług kawiarnianych}

Kawa jest używką, której spożycie jest częścią życia domowego, wypełnia przerwy w pracy i jest ważną częścią życia towarzyskiego. Spożywanie dobrej kawy poza domem jest częstą praktyką stosowaną przez konsumentów w Polsce, zwłaszcza w miastach. W ostatnim 15 - leciu spożycie kawy w Polsce wzrastało w tempie 1\% rocznie i doszło w 2015 roku do około $3 \mathrm{~kg}$ na osobę rocznie. Wzrost spożycia kawy wiąże się w znacznym stopniu z rozwojem usług ka- 
of café services. It is estimated that in 2015, the Poles spent nearly half a billion zlotys in cafés (PMR 2015 Report).

The cafeteria market is a part of the catering market, which includes hotel gastronomy (Ho), restaurants (Re) and catering (Ca). Each of these segments of the catering market is quite diverse and each one contains an element of coffee consumption. Cafés, as service facilities, constitute a separate part of the restaurant market segment and their turnover at the end of 2014 was estimated at PLN 1,833 million, which accounted for approximately $10 \%$ of the turnover of the restaurant market. The total value of the HoReCa market at the end of 2014 amounted to PLN 23,431 million. (PMR Report 2015, Bartkowicz 2015).

Several sub-segments differing in product specialization, targeting different consumer groups, the scale of the services provided, the organizational and legal form of running a business and other features of a service provider can be distinguished in the cafeteria market. In Poland, there are both network and local posts, large and small facilities, attractively located and equipped, as well as facilities with standard features.

Despite the dominance of large network enterprises on the market of café services, entering this market and running a café is an idea that is taken quite often. There are three ways to start a business in this sector: opening a company under its own brand, joining the franchise network and cooperating on the basis of an agency agreement. Regardless of the choice of the business model, it is necessary to register the company and fulfil a number of other duties, organizational activities and financial expenditures.

Each business model of launching café services has its advantages and disadvantages. Doing business on your own is connected with high capital involvement and high risk. In order to promote your own brand you need capital, experience in the industry, good business contacts and effective marketing. Opening your own café is related to finding a suitable place in a favourable location, defining the profile and scope of services, obtaining a permit, equipment and equipping the facility with furniture and technical equipment, staffing and organizing accounting, developing and implementing promotions by means of marketing instruments. The costs associated with running cafés include the costs of obtaining permits, administrative fees and licenses, purchase costs, equipment and preparation of premises, costs of equipment and purchase of materials, costs of employment, bookkeeping and marketing. According to the specialists' estimation, preparation of premises for one's own café requires investing PLN 100,000 to 400,000 , and the equipment of a coffee shop is an expense from PLN 50,000 to 150,000 . (Ziółkowska 2016).

The franchise systemis a model that enablesa brand owner to develop a network based on cooperation with individual enterprises by granting permission, license, consent to offer products or services on wiarnianych. Szacuje się, że w 2015 roku Polacy wydali w kawiarniach blisko pół miliarda złotych (Raport PMR 2015).

Rynek kawiarniany stanowi część rynku gastronomicznego, który obejmuje gastronomię hotelową (Ho), restauracje (Re) i catering (Ca). Każdy z tych segmentów rynku gastronomicznego jest dość mocno zróżnicowany i każdy zawiera element spożycia kawy. Kawiarnie, jako obiekty usługowe, stanowią wyodrębnioną część segmentu rynku restauracyjnego a ich obroty na koniec 2014 roku szacowane były na 1833 mln złotych, co stanowiło około $10 \%$ obrotów rynku restauracyjnego. Ogólna wartość rynku HoReCa na koniec 2014 roku wynosiła 23431 mln zł. (Raport PMR 2015, Bartkowicz 2015).

Na rynku kawiarnianym można wyróżnić kilka podsegmentów różniących się specjalizacją produktową, ukierunkowaniem na różne grupy konsumentów, skalą świadczonych usług, organizacyjno-prawną formą prowadzenia biznesu i innymi cechami placówki świadczącej usługi. W Polsce funkcjonują zarówno placówki sieciowe jak i placówki lokalne, obiekty duże i małe, atrakcyjnie usytuowane i wyposażone oraz placówki o cechach standardowych.

Mimo dominacji dużych przedsiębiorstw sieciowych na rynku usług kawiarnianych wejście na ten rynek i prowadzenie kawiarni to pomysł, który podejmowany jest dość często. Do rozpoczęcia działalności w tym sektorze prowadzą trzy drogi: otworzenie firmy pod własną marką, przystąpienie do sieci franczyzowej i współpraca w oparciu o umowę ajencyjną. Niezależnie od wyboru modelu biznesowego konieczne jest zarejestrowanie firmy oraz spełnienie szeregu innych obowiązków, działań organizacyjnych i nakładów finansowych.

Każdy model biznesowy uruchomienia usług kawiarnianych ma swoje zalety i wady. Prowadzenie działalności na własną rękę związane jest $\mathrm{z}$ wysokim zaangażowaniem kapitału oraz dużym ryzykiem. Do wypromowania własnej marki potrzebny jest kapitał, doświadczenie w branży, dobre kontakty handlowe oraz skuteczny marketing. Otwarcie własnej kawiarni wymaga znalezienia odpowiedniego lokalu w korzystnej lokalizacji, określenia profilu i zakresu usług, uzyskania pozwolenia, urządzenia i wyposażenia obiektu w meble i sprzęt techniczny, zatrudnienia personelu i zorganizowania księgowości, opracowania i wdrożenia promocji przy zastosowaniu instrumentów marketingowych. Koszty związane $\mathrm{z}$ uruchamianiem kawiarni obejmują koszty uzyskania pozwoleń, opłat administracyjnych i licencji, koszty pozyskania, urzadzenia i przygotowania lokalu, koszty wyposażenia w sprzęt i zakupu materiałów, koszty zatrudnienia, prowadzenia księgowości i marketingu. Według szacunku specjalistów samo przygotowanie lokalu dla własnej kawiarni wymaga zainwestowania 100 - 400 tys. zł., a wyposażenie kawiarni to wydatek od 50 do 150 tys. zł. (Ziółkowska 2016).

System franczyzowy to model, który umożliwia właścicielowi marki rozwój sieci na podstawie współpracy z indywidualnymi przedsiębiorstwami przez odpłatne udzielenie pozwolenia, licencji, zgo- 
his behalf and use of his trade name, trademark, company logo and application of prices adopted by them (Stawicka 2009). The franchiser provides the name, trademark and know-how. A franchisee can be a natural or legal person who is able to use these attributes and conduct business in exchange for a license fee. Within this fee, the franchisee has a possibility to learn, participate in the trainings and be introduced to the methods of managing and keeping accounts, operating equipment, carrying out marketing activities, etc. Depending on the network, apart from the license fees, turnover, marketing and other fees may also be charged. The franchise business makes it easier for a budding entrepreneur to gain customer trust. Just as when opening a café under its own brand, the franchisee is obliged to find premises and appropriate permits. The franchisee must also cover the cost of equipment, accounting and employment.

Running a franchise cafeteria offers many opportunities but involves significant costs. They consist of initial license fees and regular running charges, usually set as a percentage of the turnover obtained by the franchisee. The amount of current charges sometimes reaches $15-25 \%$ of the monthly turnover. Some networks charge a fixed amount of the ongoing fee apart, irrespective of the turnover. There are also networks that do not charge current fees, as in the case of A. Blikle café , which includes the current charges in the price of the goods. Some networks charge extra fees for a common advertising fund.

Investments in the launch of a franchise café are estimated at approximately PLN 200,000. The offers for starting a café in the franchise system are within the limits of PLN 80 - 550 thousand. The cheapest offer has the network of mini cafés under the name Coffee Shop Company and the most expensive - the network Cafe Chopin. The most popular Polish chain of cafés operating in the franchise system is the Columbus Coffee chain which has been operating since 1999 and runs about 20 cafés in various Polish cities. This chain, as one of the few chains, departs from the interior design common to all. Columbus Coffee also helps franchisees to obtain leasing of specialist equipment and furnishing of cafés. Moreover, it organises courses for employees and makes it easier both to set up and run a café during the first few weeks of operation. Among the popular franchisers there is also a network of cafés and confectioneries A. Blikle, So!Coffee or Organic Coffee. Each of these networks organises a franchise on an individual basis and differing to a large extent in financial and organisational conditions (Ziółkowska 2016).

Organising cafés in a network system has both advantages and disadvantages. The advantage is that it is possible to use a proven concept and a specific business plan. The franchisee limits the risk by using the franchiser's analyses, researches on local markets, knowledge, competence and experience both at the stage of the idea of setting up a business, searching for premises and starting business activity. Opening a café under both the well-known brand dy na oferowanie produktów lub świadczenie usług w jego imieniu oraz używanie jego nazwy handlowej, znaku towarowego, logo firmy a także stosowanie przyjętych przez nich cen (Stawicka 2009). Franczyzodawca udostępnia nazwę, znak towarowy i know -how. Franczyzobiorcą może być osoba fizyczna lub prawna, która ma możliwość wykorzystania tych atrybutów i prowadzenia działalności w zamian za opłatę licencyjną. W ramach tej opłaty franczyzobiorca ma możliwość nauki, szkoleń, poznania metod zarządzania i prowadzenia księgowości, obsługi sprzętu, prowadzenia marketingu itp. W zależności od sieci, oprócz opłat licencyjnych mogą pojawiać się opłaty od obrotów, opłaty marketingowe i inne. Działalność $\mathrm{w}$ ramach franszyzy ułatwia poczatkującemu przedsiębiorcy zdobycie zaufania klientów. Podobnie jak przy otwieraniu kawiarni pod własną marka, franczyzobiorca zobligowany jest do znalezienia lokalu oraz odpowiednich zezwoleń. Musi również pokryć koszt wyposażenia, koszty prowadzenia księgowości oraz zatrudnienia pracowników.

Prowadzenie kawiarni w ramach franczyzy daje wiele możliwości ale wiąże się ze znacznymi kosztami. Składają się na nie wstępne opłaty licencyjne oraz cykliczne opłaty bieżące ustalane zazwyczaj jako procent od obrotu uzyskanego przez franczyzobiorcę. Wysokość opłat bieżących sięga niekiedy $15-25 \%$ obrotu miesięcznego. Niektóre sieci pobierają stałą wysokość opłaty bieżącej niezależnie od obrotu. Są również sieci, które nie pobierają opłat bieżących, jak w przypadku kawiarni A. Blikle, która włącza opłaty bieżące w cenę towaru. Niektóre sieci pobierają dodatkowo opłaty na wspólny fundusz reklamowy.

Inwestycje $\mathrm{w}$ uruchomienie kawiarni w systemie franczyzowym szacuje się na kwotę około 200 tys. zł. Oferty uruchomienia kawiarni w systemie franczyzowym mieszczą się w granicach 80 - 550 tys. zł. Najtańszą ofertę przedstawia sieć mini kawiarni pod nazwą Coffee Shop Company zaś najdroższą sieć Cafe Chopin. Najpopularniejszą polską siecią kawiarni działającą w systemie franczyzowym jest działająca od 1999 r. sieć Columbus Coffee, która prowadzi około 20 kawiarni w rożnych miastach Polski. Sieć ta, jako jedna z nielicznych sieci odchodzi od wspólnego dla wszystkich wystroju wnętrza. Columbus Coffee pomaga również franczyzobiorcom w uzyskaniu leasingu na sprzęt specjalistyczny i wyposażenie kawiarni, organizuje szkolenia pracowników i pomaga uruchomić i prowadzić kawiarnię przez pierwsze tygodnie funkcjonowania. Do popularnych franczyzodawców można zaliczyć także sieć kawiarnio-cukierni A. Blikle, So!Coffee czy Organic Coffee. Każda z tych sieci organizuje franczyzę na indywidualnych zasadach i różniących się w znacznym stopniu warunkach finansowych i organizacyjnych (Ziółkowska 2016).

Organizowanie kawiarni w układzie sieciowym ma zarówno zalety jak i wady. Zaletą jest to, że korzysta się ze sprawdzonej koncepcji i określonego biznes planu. Franczyzobiorca ogranicza ryzyko poprzez korzystanie $\mathrm{z}$ analiz, badań rynków lokalnych przez franczyzodawcę oraz z jego wiedzy, kompetencji i doświadczenia zarówno na etapie pomysłu podjęcia działalności, poszukiwania lokalu i urucho- 
and the logo of the licensor we have a better chance to negotiate an affordable rental charge, to obtain official permits as well as to equip and furnish the premises properly. Often, franchisers take over the responsibility for the execution of matters related to obtaining permits for the activity in a given location. Large networks advertise on a large scale and thereby relieve franchisees who profit from the prices and discounts negotiated for the entire network.

In the case of network premises, franchisers usually rely on ready-made and universal solutions. It is very seldom for a franchisee to give an individual style and character to a café . The franchisee is not able to create his own menu, and often cannot choose suppliers of products. It may be dangerous to conduct a licensed business if consumers are dissatisfied with one place in the network because this opinion can influence the entire network. The disadvantages of the franchise system include also the fact of bearing regular charges for the benefit of the licensor and the application of contractual penalties, which limit their profits. The terms of the license are not often stated precisely, which may cause tensions, conflicts and the application of contractual penalties. International and global companies with a high brand recognition require a stringent application of the established pattern and do not allow for departures from the standard style of the premises and its furnishings. Smaller networks are more flexible in this respect.

A dealership system belonging to business intermediation means a concept in which an agent is responsible for running commercial or service points, but acts to the advantage of the client. Agents sell goods owned by the client or provide services for and on behalf of the orderer. Based on an agency agreement, the contractor (agent) undertakes, in the scope of his business, to a regular mediation, for a fee, to conclude contracts with clients for the benefit of an entrepreneur who acts as a principal or to conclude contracts on his behalf (Act of July 22, 1964).

The main differences between an agency agreement and a franchise agreement are that the agent, contrary to the franchisee, executes contracts for or on behalf of the principal. The franchisee always works for his own account and on his own behalf. In the agency system, one does not work for one's own account, but on behalf of the headquarters. In the case of a dealership agreement, the whole sale in the café is registered for the benefit of the principal. The entire revenue from the sales earned in a local branch goes to the franchisee's account. Therefore, another important difference lies in the remuneration. The franchisee pays the remuneration to a franchiser in the form of, for example, a commission on the turnover or income. In the dealership agreement, the agent receives remuneration for his activities from the client in the form of a commission, which is usually expressed as a percent on the turnover specified in the contract. One can find contracts in which, apart from the commission, the agent receives a fixed basis of remuneration regardless of the turnover. It should also be emphasised that the agency agreement, unlike the franchise agreement, does not provide the agent mienia działalności. Otwierając kawiarnię pod znaną marką i logo licencjodawcy mamy większe szanse na negocjacje korzystnej ceny najmu lokalu i jej odpowiedniego wyposażenia i urządzenia oraz uzyskania formalnych zezwoleń urzędowych. Franczyzodawcy często przejmują na siebie wykonanie spraw związanych z uzyskaniem zezwoleń na działalność w danej lokalizacji. Duże sieci prowadzą reklamę o szerokim zasięgu odciążając tym samym franczyzerów. Franczyzanci korzystają z cen i rabatów wynegocjowanych dla całej sieci.

W przypadku lokali sieciowych franczyzodawcy bazują zazwyczaj na gotowych, uniwersalnych rozwiązaniach. Rzadko się zdarza, aby franczyzant mógł nadać kawiarni indywidualny styl i charakter. Franczyzobiorca nie ma możliwości ustalenia własnego menu, często też nie może wybierać dostawców produktów do lokalu. Niebezpieczne dla prowadzenia działalności na licencji jest to, że jeśli konsumenci są niezadowoleni z jednego lokalu w sieci to ta opinia może się przenieść na całą sieć. Do wad systemu franczyzowego należy również zaliczyć fakt ciągłego ponoszenia opłat na rzecz licencjodawcy oraz stosowanie kar umownych, co ogranicza ich zyski. Często warunki licencji nie są dopracowane w szczegółach co powodować może napięcia, konflikty i zastosowanie kar umownych. Międzynarodowe firmy globalne $\mathrm{z}$ dużą rozpoznawalnością marki wymagają sztywnego stosowania ustalonego wzorca i nie dopuszczają do odstępstw od standardowego stylu lokalu i jego wyposażenia. Mniejsze sieci są bardziej elastyczne pod tym względem .

System ajencyjny należący do pośrednictwa gospodarczego oznacza koncepcję, w której agent odpowiedzialny jest za prowadzenie punktów handlowych czy usługowych lecz działa na dobro zleceniodawcy. Agenci zbywaja towary będące własnością zleceniodawcy lub świadczą usługi w imieniu i na rzecz dającego zlecenie. Przez umowę agencyjną przyjmujący zlecenie (agent) zobowiązuje się, $\mathrm{w}$ zakresie działalności swojego przedsiębiorstwa, do stałego pośredniczenia, za wynagrodzeniem, przy zawieraniu z klientami umów na rzecz dającego zlecenie przedsiębiorcy albo do zawieraniu umów $\mathrm{w}$ jego imieniu (Ustawa z 22 lipca 1964).

Główne różnice występujące między umową agencyjną, a franczyzową polegają na tym, że agent, $w$ przeciwieństwie do franczyzanta, zawiera umowy $\mathrm{w}$ imieniu dającego zlecenie lub na jego rzecz. Franczyzobiorca zawsze działa na własny rachunek i we własnym imieniu. W systemie agencyjnym nie pracujemy na swoje konto, lecz w imieniu centrali. W przypadku umowy ajencyjnej cała sprzedaż w kawiarni rejestrowana jest na rzecz dającego zlecenie. Sprzedaż w placówce działającej na licencji trafia w całości na rachunek franczyzobiorcy. W związku z tym kolejna ważna różnica tkwi w wynagrodzeniu. Franczyzobiorca płaci wynagrodzenie franczyzodawcy w postaci np. prowizji od obrotu czy dochodu. W umowie ajencyjnej agent otrzymuje wynagrodzenie za swoje działania od zleceniodawcy w postaci prowizji, która zazwyczaj stanowi określony w umowie procent od obrotu. Można spotkać umowy, w których oprócz 
with the principal's know-how. The agent does not acquire a license to use the brand or the trademark.

So!Coffee network is an example of a café offering cooperation based on an agency agreement. The advantage of an agency, compared to the activities conducted for one's own account and on the basis of a franchise, is a much lower initial cost of starting the business. This results from the fact that the premises are owned by the network that prepares and arranges them, and the agent is only responsible for conducting the business. However, the agent pays a deposit in order to secure the entrusted premises and equipment. An agency agreement is less risky than other business forms, but the profit generated in the branch belonging to the agent belongs entirely to the network owners. The agent has minimum freedom of action and has no influence on the prices or margins.

By choosing a business method, investors must refer to their financial resources, the possibility of obtaining funds from external sources and a range of matters related to obtaining and furnishing the premises, employment of personnel, acquiring administrative decisions, etc. It is important to consider the likelihood and forms of risk when investing and conducting a business. Threats may arise not only in the capital and financial aspect but also on the emotional and psychological levels. Psychological illusions and a desire for quick profit may distort the course of the investment and disrupt the anticipated and expected image (Ziółkowska 2016).

\section{Business plan of the investment project}

Starting a business on the market of coffee services requires developing a proper business plan that includes: a detailed description of the business, specification of the rules and methods of financing, determination of the size of human resources and marketing plan, financial plan and SWOT analysis (Skrzypek 2009, Gabrusewicz 2014, Bednarski 2011, Łukasik 2006). The outline of such a plan to run a café in Warsaw covers the above-mentioned elements, but focuses on financial aspects. The task of the plan is to present the most important issues related to the launch and operation of cafés and to show, based on specific examples and numbers, how the potential capabilities of the company are shaped. The following assumptions were made for the creation of the business plan (Ziółkowska 2016):

- The investor is a natural person running a sole proprietorship,

- The investment place is Warsaw,

- The investor considers three options of running a business: opening a café under his own brand, franchise of the concept of A. Blikle or cooperation as an agent with the So!Coffee network,

- Two locations have been taken into account, in addition to the possibility of opening a café prowizji agent otrzymuje stałą podstawę wynagrodzenia niezależną od obrotu. Należy także podkreślić fakt, że umowa agencji, w odróżnieniu od umowy franczyzowej, nie przewiduje udostępnienia agentowi przez zleceniodawcę know-how. Agent nie nabywa również licencji na posługiwanie się marką czy znakiem handlowym.

Przykładem kawiarni oferującej współpracę w oparciu o umowę agencyjną jest sieć So!Coffee. Zaletą agencji, w porównaniu do działalności na rachunek własny i na podstawie franszyzy, jest znacznie mniejszy koszt początkowy uruchomienia działalności, Wynika to z tego, że lokal jest własnością sieci, sieć przygotowuje i urządza lokal a agent go tylko prowadzi. Agent wpłaca jednak kaucję zabezpieczającą powierzony lokal i wyposażenie. Umowa agencyjna obarczona jest mniejszym ryzykiem niż inne formy biznesowe ale zysk wypracowany w placówce agenta w całości należy do właścicieli sieci. Agent ma minimalną swobodę działania i nie ma wpływu na ceny ani marże.

Wybierając sposób działalności biznesowej inwestorzy muszą odnieść się do posiadanych zasobów finansowych, możliwości pozyskania środków ze źródeł zewnętrznych i kompleksu spraw związanych z pozyskaniem lokalu, jego urządzeniem i wyposażeniem, zatrudnieniem personelu, uzyskaniem decyzji administracyjnych itp. Ważną sprawą jest oszacowanie prawdopodobieństwa i form ryzyka w trakcie inwestowania i prowadzenia działalności. Zagrożenia mogą pojawić się nie tylko w sferze kapitałowo -finansowej ale także w sferze emocjonalnej i psychologicznej. Psychologiczne iluzje i żądza szybkiego zysku mogą wypaczyć przebieg inwestycji i zakłócić przewidywany i oczekiwany jej obraz (Ziółkowska 2016).

\section{Plan biznesowy przedsięwzięcia inwestycyjnego}

Rozpoczęcie działalności na rynku usług kawiarnianych wymaga opracowania odpowiedniego planu biznesowego, który obejmuje: szczegółowy opis działalności, określenie zasad i sposobów finansowania, określenie wielkości zasobów ludzkich i planu marketingowego, plan finansowy i analiza SWOT (Skrzypek 2009, Gabrusewicz 2014, Bednarski 2011, Łukasik 2006 ). Zarys takiego planu uruchomienia kawiarni w Warszawie obejmuje wyżej wymienione elementy lecz skupia się na aspektach finansowych. Zadaniem planu jest przedstawić najważniejsze kwestie związane $\mathrm{z}$ uruchomieniem i prowadzeniem kawiarni oraz pokazać na konkretnych przykładach i liczbach jak kształtują się potencjalne możliwości firmy. Do stworzenia biznes planu przyjęto następujące założenia (Ziółkowska 2016):

- Inwestor jest osobą fizyczną prowadzącą jednoosobową działalność gospodarczą,

- Miejscem inwestycji jest Warszawa,

- Inwestor rozważa trzy opcje prowadzenia biznesu: otwarcie kawiarni pod własną marką, franczyza konceptu firmy A. Blikle lub współpraca jako Ajent z siecią kawiarni So!Coffee,

- Pod uwagę wzięte zostały dwie lokalizacje, w których oprócz możliwości otwarcia kawiar- 
under own brand or in a franchise, the offer of cooperation as a Business Partner of So!Coffee is also available,

- The premises have an area of $70 \mathrm{~m}^{2}$ and are adapted in the basic elements to run a café with 20 seats.

The assortment in all cases is the same. In addition to a variety of coffee made on site there are also: cakes, pies, ice-cream, soft drinks and alcohol up to $18 \%$ (sold only for take away).

The planned investment project involves running a café in Warsaw in one of two places: in the Arkadia Shopping Centre or in the premises at Nowy Świat street. Both locations are very attractive because they belong to the Śródmieście district and are located in the busiest places of the capital. It is the largest and most competitive commercial market in Poland. The purchasing power for consumption outside home in the capital of Poland exceeds the national average over two and a half times (Trade Report 2015). In the catering category, commercial street and residential premises are more popular among Varsovians than restaurants, bars and other food outlets located in shopping centres. However, the increasing popularity of shopping centres as places of spending free time means that the use of cafés, bars and restaurants located in these facilities permanently fits into consumer habits (Commercial Report 2015). According to a survey carried out by ARC Rynek i Opinia, as many as $61 \%$ of Poles visiting the shopping centre use the offer of catering. In turn, in the research carried out by PMR, 38\% of Poles admit that they use gastronomic offer in a shopping centre more often than once a month or even several times a week (PMR 2015 Report).

The ability to serve clients both at the premises located in the Arkadia Shopping Centre as well as at the premises at Nowy Świat street is small compared to the demand. This is evidenced by the fact that on weekends it is difficult to find vacancy in any café located there. The Arkadia Shopping Centre has 287 thousand $\mathrm{m} 2$ of the usable area, there are 255 stores, 22 restaurants, a 15 -screens cinema Cinema City and a two-storey car park. The Arkadia Shopping Centre retail area is over $110,000 . \mathrm{m}^{2}$, which makes it one of the largest shopping centres in Europe. In 2013, 21 million people visited the Arkadia Shopping Centre. According to a research conducted by the consulting firm Colliers International, $38 \%$ of the Warsaw residents surveyed prefer shopping in the Arkadia Shopping Centre (PMR 2015 Report). The SWOT analysis of the coffee shop in the Arkadia Shopping Centre is presented in Table 1.

Nowy Świat street is one of the main streets of Warsaw, part of the historic Royal Route, eagerly visited by both Warsaw residents and tourists. Warsaw's Nowy Świat is the most expensive street in Poland, it is ranked 43 in the world ranking of the most expensive shopping streets in the world. The average rent per square meter costs EUR 1020 per year (PMR 2015 Report). SWOT analysis of a café located at Nowy Świat street is presented in Table 2.

The offer of gastronomic points located at the ni pod własna marką lub we franczyzie dostępna jest oferta współpracy jako Business Partner kawiarni So!Coffee,

- Lokale mają powierzchnię $70 \mathrm{~m}^{2}$ oraz są dostosowane w podstawowych kwestiach do prowadzenia kawiarni posiadających 20 miejsc siedzących.

Asortyment we wszystkich przypadkach jest taki sam. Oprócz różnego rodzaju kawy przyrządzanej na miejscu dostępne sa ciasta, torty, lody, napoje bezalkoholowe oraz alkohol do 18\% sprzedawany jedynie na wynos.

Planowane przedsięwzięcie inwestycyjne zakłada prowadzenie kawiarni $\mathrm{w}$ Warszawie $\mathrm{w}$ jednym z dwóch miejsc: w Centrum Handlowym Arkadia lub w lokalu przy ul. Nowy Świat. Obie lokalizacje sa bardzo atrakcyjne, ponieważ należą do Śródmieścia oraz znajdują się w najbardziej ruchliwych miejscach stolicy. Jest największym i najbardziej konkurencyjnym rynkiem handlowym w Polsce. Siła nabywcza na konsumpcję poza domem w stolicy Polski przekracza średnią ogólnopolską przeszło dwuipółkrotnie (Raport Handlowy 2015). W kategorii gastronomicznej lokale przy ulicach handlowych i w lokalizacjach rezydencjalnych cieszą się większą popularnością wśród warszawiaków niż restauracje, bary i inne punkty gastronomiczne zlokalizowane $\mathrm{w}$ centrach handlowych. Jednak wzrastająca popularność centrów handlowych, jako miejsc spędzania wolnego czasu sprawia, że korzystanie z kawiarni, barów i restauracji znajdujących się w tych obiektach na stałe wpisuje się w zwyczaje konsumenckie (Raport handlowy 2015). Według badania przeprowadzonego przez ARC Rynek i Opinia aż 61\% Polaków odwiedzając centrum handlowe korzysta z oferty części gastronomicznej. Z kolei $w$ badaniach przeprowadzonych przez firmę PMR 38\% Polaków przyznaje, że korzysta z oferty gastronomicznej $w$ centrum handlowym częściej niż raz w miesiącu, a nawet kilka razy w tygodniu (Raport PMR 2015).

Zdolność do obsługi klientów zarówno w lokalach znajdujących się w CH Arkadia jak i w lokalach przy ul. Nowy Świat jest mała w stosunku do popytu. Świadczy o tym chociażby fakt, że w weekendy trudno jest znaleźć wolne miejsce w jakiejkolwiek kawiarni. Arkadia ma 287 tys. m2 powierzchni użytkowej, znajduje się tam 255 sklepów, 22 restauracje, 15-ekranowe kino Cinema City oraz dwupoziomowy parking. Powierzchnia handlowa Arkadii wynosi ponad 110 tys. $\mathrm{m}^{2}$, co czyni ją jednym z największych centrów handlowych w Europie. W 2013 r. odwiedziło Arkadię 21 mln ludzi. Według badań firmy doradczej Colliers International 38\% ankietowanych mieszkańców Warszawy preferuje zakupy w $\mathrm{CH}$ Arkadia (Raport PMR 2015). Analiza SWOT kawiarni w CH Arkadia przedstawia tabela 1.

Ulica Nowy Świat jest jedną z głównych ulic Warszawy, stanowiącą część historycznego Traktu Królewskiego, chętnie odwiedzaną zarówno przez mieszkańców Warszawy jak i turystów. Warszawski Nowy Świat jest najdroższą ulicą w całej Polsce, zajmuje 43 miejsce w światowym rankingu najdroższych ulic handlowych na świecie. Średni czynsz za 
Nowy Świat street and in the Arkadia Shopping Centre is rich and diverse. Both locations are characterized by strong competition. In the Arkadia Shopping Centre there are 13 brands with a total of 16 points of sale belonging to the group "Cafes and Confectioneries". Restaurants with a similar product offer, include Costa Coffee Café, Green Cafe Nero and Cafe Vincent. However, it should be remembered that the selection of companies that open their points in shopping centres is heavily controlled and checked many times to meet the objectives set by the shopping centre.

Table 1. SWOT analysis of a café in the Arkadia Shopping Centre

\begin{tabular}{|c|c|}
\hline \multicolumn{2}{|c|}{ Internal conditions } \\
\hline Strengths & Weaknesses \\
\hline $\begin{array}{l}\text { - one of three shopping } \\
\text { centres in Warsaw with the } \\
\text { highest number of visitors } \\
\text { - constant increase in the } \\
\text { number of visitors, } \\
\text { - one of the most fashionable } \\
\text { and the best quality } \\
\text { shopping centres in Poland }\end{array}$ & $\begin{array}{l}\text { - high rent, } \\
\text { - high costs of adapting the } \\
\text { premises, } \\
\text { - restrictive regulations of } \\
\text { the shopping centre } \\
\text { - strong security for the } \\
\text { lease agreement, } \\
\text { - no possibility of breaking } \\
\text { the contract before the } \\
\text { ending period } \\
\text { - it is not possible to run } \\
\text { additional off-premises } \\
\text { sales }\end{array}$ \\
\hline \multicolumn{2}{|c|}{ External conditions } \\
\hline Opportunities & Threats \\
\hline $\begin{array}{l}\text { - well-known composition } \\
\text { of tenants (competition) } \\
\text { during the lease period } \\
\text { - the possibility of increasing } \\
\text { sales through the } \\
\text { comprehensive nature of } \\
\text { the services provided } \\
\text { - the possibility of additional } \\
\text { income by acquiring } \\
\text { customers - shopping } \\
\text { centre employees - about } \\
500 \text { people }\end{array}$ & $\begin{array}{l}\text { - limitations of the } \\
\text { marketable range - } \\
\text { regulated by the lease } \\
\text { agreement } \\
\text { - fixed days and opening } \\
\text { hours, without the } \\
\text { possibility of changing, } \\
\text { closed on public holidays } \\
\text { - a new shopping centre may } \\
\text { appear in the area to which } \\
\text { the customers may leave, } \\
\text { - Trade Act }\end{array}$ \\
\hline
\end{tabular}

Source: own study.

There are 14 premises within the Nowy Świat street that have a café-confectionery offer. The competitors are Costa Coffee, Vincent, Starbucks and Cava. In the case of catering outlets located at the Nowy Świat street the rotations are more frequent than in the shopping centre; there is also a higher risk. In the Arkadia Shopping Centre, there is a possibility to hedge against risks when negotiating the terms of the agreement.

Regardless of the choice of the business model in which the café will be run, the investor decides about the issues related to the recruitment and employment. Due to different opening hours of the coffee shop in both locations, the number of people employed will vary. The shopping centre imposes an obligation to metr kwadratowy wynosi tutaj 1020 euro rocznie (Raport PMR 2015). Analizę SWOT kawiarni zlokalizowanej przy ul. Nowy Świat przedstawia tabela 2.

Oferta punktów gastronomicznych znajdujących się przy ul. Nowy Świat oraz w C.H. Arkadia jest bogata i zróżnicowana. Obie lokalizacje charakteryzują się silną konkurencją. W CH Arkadia znajduje się 13 marek posiadających łącznie 16 punktów sprzedaży należących do grupy „Kawiarnie i Cukiernie”. Do lokali o podobnej ofercie produktowe, należy kawiarnia Costa Coffee, Green Caffe Nero oraz Cafe Vincent. Należy jednak pamiętać, że dobór firm, które otwieraja swoje punkty w centrach handlowych jest mocno kontrolowany i wielokrotnie sprawdzany tak, by odpowiadał celom ustalonym przez centrum handlowe.

Tabela 1. Analiza SWOT kawiarni w Centrum Handlowym Arkadia

\begin{tabular}{|c|c|}
\hline \multicolumn{2}{|c|}{ Uwarunkowania wewnętrzne } \\
\hline Mocne strony & Słabe strony \\
\hline $\begin{array}{l}\text { - jedno z trzech centrów } \\
\text { handlowych w Warszawie } \\
\text { z największą liczbą } \\
\text { odwiedzających } \\
\text { - stały wzrost liczby } \\
\text { odwiedzających, } \\
\text { - jedna z najbardziej } \\
\text { modnych i najlepszych } \\
\text { jakościowo galerii } \\
\text { handlowych w Polsce }\end{array}$ & $\begin{array}{l}\text { - wysoki czynsz, } \\
\text { - wysokie koszty adaptacji } \\
\text { lokalu, } \\
\text { - restrykcyjny regulamin CH } \\
\text { - mocne zabezpieczenia } \\
\text { umowy najmu, } \\
\text { - brak możliwości zerwania } \\
\text { umowy przed okresem } \\
\text { zakończenia } \\
\text { - brak możliwości } \\
\text { prowadzenia dodatkowej } \\
\text { sprzedaży poza lokalem }\end{array}$ \\
\hline \multicolumn{2}{|c|}{ Uwarunkowania zewnętrzne } \\
\hline Szanse & \begin{tabular}{|l|} 
Zagrożenia \\
\end{tabular} \\
\hline $\begin{array}{l}\text { - znany skład najemców } \\
\text { (konkurencji) w okresie } \\
\text { najmu } \\
\text { - możliwość zwiększenia } \\
\text { sprzedaży przez } \\
\text { kompleksowość } \\
\text { świadczonych usług } \\
\text { - możliwość dodatkowych } \\
\text { wpływów przez } \\
\text { pozyskanie klientów } \\
\text { - pracowników galerii - } \\
\text { około } 500 \text { osób }\end{array}$ & $\begin{array}{l}\text { - ograniczenia asortymentu } \\
\text { możliwego do sprzedaży- } \\
\text { regulowane umową najmu } \\
\text { - stałe dni i godziny } \\
\text { otwarcia, bez możliwości } \\
\text { zmiany, nieczynne } \\
\text { w święta } \\
\text { - w okolicy może pojawić się } \\
\text { nowe centrum handlowe do } \\
\text { którego odejdą klienci, } \\
\text { - ustawa o handlu }\end{array}$ \\
\hline
\end{tabular}

Źródło: Opracowanie własne.

W ciągu ulicy Nowy Świat znajduje się 14 lokali, które posiadają ofertę kawiarniano-cukierniczą. Konkurencję stanowią marki Costa Coffee, Vincent, Starbucks oraz Cava. W przypadku punktów gastronomicznych znajdujących się przy ul. Nowy Świat występują częstsze rotacje niż w centrum handlowym, tu występuje również większe ryzyko. W CH Arkadia istnieje możliwość zabezpieczenia się przed ryzykiem przy negocjacjach warunków umowy.

Niezależnie od wyboru modelu biznesowego, w którym będzie prowadzona kawiarnia, do inwestora należą kwestie dotyczące rekrutacji i zatrudnienia pracowników. Ze względu na różne godziny otwarcia kawiarni w obu lokalizacjach ilość osób zatrudnionych będzie się różniła. Centrum handlowe 
ensure the continuity of the business premises by opening it on certain days and hours. Failure to do this may result in financial sanctions or even termination of the lease contract. There are also other obligations regarding the range of products and the aesthetics of the interior. The café in the Arkadia Shopping Centre will be open for 12 hours a day, employing 5 people, it gives 860 hours of the total working time, which for an employer amounts to PLN 11 609. In its own facility, at the Nowy Świat street, 15 working hours for 6 employees have been estimated, which gives the total time of 1020 hours generating the employer's cost of PLN 14 511. (Ziółkowska 2016).

Table 2. SWOT analysis of a café at the Nowy Świat street

\begin{tabular}{|c|c|}
\hline \multicolumn{2}{|c|}{ Internal conditions } \\
\hline Strengths & Weaknesses \\
\hline $\begin{array}{l}\text { - perfect location at one } \\
\text { of the most fashionable } \\
\text { Warsaw streets with the } \\
\text { highest number of tourists } \\
\text { - eagerly visited by the } \\
\text { residents of Warsaw }\end{array}$ & $\begin{array}{l}\text { - turnover depending on } \\
\text { the weather and seasons - } \\
\text { strong seasonality } \\
\text { - greater rent than other } \\
\text { street locations }\end{array}$ \\
\hline \multicolumn{2}{|c|}{ External conditions } \\
\hline Opportunities & \begin{tabular}{|c|} 
Threats \\
\end{tabular} \\
\hline $\begin{array}{l}\text { - the possibility of } \\
\text { generating additional sales } \\
\text { in the spring and summer } \\
\text { - garden } \\
\text { - the possibility of } \\
\text { generating additional sales } \\
\text { from catering, take-away } \\
\text { sales, delivery to the } \\
\text { customer } \\
\text { - full flexibility in adjusting } \\
\text { the opening days and hours } \\
\text { to the forecasted sale } \\
\text { - the possibility of renting } \\
\text { the entire premises and } \\
\text { organizing closed events }\end{array}$ & $\begin{array}{l}\text { - no impact on the weather } \\
\text { (loss of sales) } \\
\text { - no impact on repairs, } \\
\text { protests, manifestations, } \\
\text { etc. (loss of sales), } \\
\text { - higher risk due to } \\
\text { devastation and terrorism } \\
\text { - a big threat of new entries } \\
\text { to the local market }\end{array}$ \\
\hline
\end{tabular}

Source: own study.

Marketing costs occur only if you run a café under your own brand. It is important to create a good marketing plan that defines the pricing strategy. The costs an investor has to incur on marketing will vary depending on the location and organizational form. In the case of the Arkadia Shopping Centre café , these costs will be lower compared to own brand due to the promotion and advertising received from the shopping centre itself. Forecasted costs of promotion and advertising of a café located in the Arkadia Shopping Centre are PLN 300 per month, and a café at the Nowy Świat street PLN 1000.

The SWOT analysis of the café conducted in the three organizational and legal forms discussed is shown in tables 3,4 and 5. nakłada obowiązek zapewnienia ciągłości funkcjonowania lokalu użytkowego poprzez otwieranie go w określonych dniach i godzinach. Za niedopełnienie tego obowiązku, grożą sankcje pieniężne, a nawet wypowiedzenie umowy najmu. Występują także inne obowiązki dotyczące asortymentu produktów i estetyki wnętrza. Kawiarnia w CH Arkadia będzie otwarta przez 12 godzin dziennie przy zatrudnieniu 5 osób daje 860 godzin łącznego czasu pracy, który dla pracodawcy stanowi koszt 11609 zł. We własnej placówce przy ul. Nowy Świat założono 15 godzinny czas pracy dla 6 pracowników, co daje łączny czas 1 020 godzin generujący koszt pracodawcy w wymiarze 14511 zł. (Ziółkowska 2016).

Tabela 2. Analiza SWOT kawiarni przy ulicy Nowy Świat

\begin{tabular}{|c|c|}
\hline \multicolumn{2}{|c|}{ Uwarunkowania wewnętrzne } \\
\hline Mocne strony & Słabe strony \\
\hline $\begin{array}{l}\text { - doskonała lokalizacja przy } \\
\text { jednej z modniejszych } \\
\text { warszawskich ulic } \\
\text { z największą liczbą } \\
\text { turystów } \\
\text { - chętnie odwiedzana przez } \\
\text { mieszkańców Warszawy }\end{array}$ & $\begin{array}{l}\text { - obrót uzależniony od } \\
\text { pogody oraz pór roku - } \\
\text { silna sezonowość } \\
\text { - większy czynsz od } \\
\text { pozostałych lokalizacji } \\
\text { ulicznych }\end{array}$ \\
\hline \multicolumn{2}{|c|}{ Uwarunkowania zewnętrzne } \\
\hline Szanse & Zagrożenia \\
\hline $\begin{array}{l}\text { - możliwość generowania } \\
\text { dodatkowej sprzedaży } \\
\text { w okresie wiosenno- } \\
\text { letnim- ogródek } \\
\text { - możliwość generowania } \\
\text { dodatkowej sprzedaży } \\
\text { z cateringu, sprzedaży na } \\
\text { wynos, dowozu do klienta } \\
\text { - pełna elastyczność } \\
\text { w dopasowaniu dni } \\
\text { i godzin otwarcia do } \\
\text { prognozowanej sprzedaży } \\
\text { - możliwość wynajęcia } \\
\text { całego lokalu i organizacji } \\
\text { imprez zamkniętych }\end{array}$ & $\begin{array}{l}\text { - brak wpływu na pogodę } \\
\text { (utrata sprzedaży) } \\
\text { - brak wpływu na remonty, } \\
\text { protesty, manifestacje itp. } \\
\text { (utrata sprzedaży), } \\
\text { - więksse ryzyko z tytułu } \\
\text { dewastacji i terroryzmu } \\
\text { - duże zagrożenie nowymi } \\
\text { wejściami na lokalny rynek }\end{array}$ \\
\hline
\end{tabular}

Źródło: Opracowanie własne.

Koszty marketingu występują wyłącznie w przypadku prowadzenia kawiarni pod własną marką. Ważne jest, aby stworzyć dobry plan marketingowy określający strategię cenową. Koszty jakie inwestor musi ponieść na marketing będą się różniły w zależności od lokalizacji i formy organizacyjnej. W przypadku kawiarni w $\mathrm{CH}$ Arkadia koszty te będą niższe w porównaniu z własną marką ze względu na promocję i reklamę, którą otrzymujemy od samego centrum handlowego. Prognozowane koszty promocji i reklamy kawiarni znajdującej się w CH Arkadia wynoszą miesięczne 300 zł, a kawiarni przy ul. Nowy Świat $1000 \mathrm{zł}$.

Analizę SWOT kawiarni prowadzonej $\mathrm{w}$ trzech omawianych formach organizacyjno-prawnych pokazują tabele 3, 4 i 5. 
Table 3. SWOT analysis of a café created under its own brand

\begin{tabular}{|c|c|}
\hline \multicolumn{2}{|c|}{ Internal conditions } \\
\hline Strengths & Weaknesses \\
\hline $\begin{array}{l}\text { - freedom in creating } \\
\text { a brand, margin and offer } \\
\text { - the possibility of obtaining } \\
\text { funding for investment }\end{array}$ & $\begin{array}{l}\text { - high competition of } \\
\text { network businesses, } \\
\text { - high expenditures and } \\
\text { a long time needed to } \\
\text { promote the café }\end{array}$ \\
\hline \multicolumn{2}{|c|}{ External conditions } \\
\hline Opportunities & Threats \\
\hline $\begin{array}{l}\text { - the ability to match } \\
\text { the investment and } \\
\text { its character to the } \\
\text { requirements of the target } \\
\text { group and potential clients } \\
\text { - full possibility of reaction } \\
\text { to the changing market } \\
\text { and conditions of sale } \\
\text { - the possibility of taking } \\
\text { part in various events } \\
\text { - the ability to quick cost } \\
\text { reduction }\end{array}$ & $\begin{array}{l}\text { - } 100 \% \text { risk of incurred } \\
\text { losses } \\
\text { - the possibility of not } \\
\text { achieving profitability } \\
\text { without the knowledge of } \\
\text { the industry } \\
\text { - the threat of not matching } \\
\text { the tastes of clients } \\
\text { - the market is dominated by } \\
\text { network cafés }\end{array}$ \\
\hline
\end{tabular}

Source: own study.

Table 4. SWOT analysis of an A. Blikle franchise café

\begin{tabular}{|c|c|}
\hline \multicolumn{2}{|c|}{ Internal conditions } \\
\hline Strengths & Weaknesses \\
\hline $\begin{array}{l}\text { - the possibility of sales } \\
\text { support by a known brand } \\
\text { - professional marketing } \\
\text { - acquiring know-how } \\
\text { - standardized product } \\
\text { quality } \\
\text { - franchiser support } \\
\text { - the possibility of } \\
\text { negotiating the lease terms }\end{array}$ & $\begin{array}{l}\text { - high financial outlay } \\
\text { related to the adaptation } \\
\text { and standardization of the } \\
\text { premises } \\
\text { - no possibility to negotiate } \\
\text { a franchise agreement and } \\
\text { lease } \\
\text { - penalties for non- } \\
\text { compliance with standards } \\
\text { - no possibility of interfering } \\
\text { with the offer }\end{array}$ \\
\hline \multicolumn{2}{|c|}{ External conditions } \\
\hline Opportunities & Threats \\
\hline $\begin{array}{l}\text { - sales of products under the } \\
\text { well-known brand existing } \\
\text { on the market for more } \\
\text { than } 140 \text { years }\end{array}$ & $\begin{array}{l}\text { - decrease in the quality and } \\
\text { sales of the entire network } \\
\text { has an impact on the sales } \\
\text { of an individual franchisee } \\
\text { - no possibility of reacting to } \\
\text { the changing market and } \\
\text { sales }\end{array}$ \\
\hline
\end{tabular}

Source: own study.

Table 5. SWOT analysis of a So!Coffee café carried out in the form of an agency

\begin{tabular}{|c|c|}
\hline \multicolumn{2}{|c|}{ Internal conditions } \\
\hline Strengths & \begin{tabular}{|l|} 
Weaknesses \\
\end{tabular} \\
\hline $\begin{array}{l}\text { - a recognizable brand with } \\
\text { a good reputation } \\
\text { - low financial expenses for } \\
\text { starting the business } \\
\text { - professional marketing and } \\
\text { regular sales support } \\
\text { - incentive programs for } \\
\text { sellers } \\
\text { - support in covering losses } \\
\text { and gaps } \\
\text { - low operating costs }\end{array}$ & $\begin{array}{l}\text { - low compensation, } \\
\text { depending on the sales } \\
\text { - numerous checks and } \\
\text { audits } \\
\text { - penalties for non- } \\
\text { compliance with the terms } \\
\text { of the agency contract }\end{array}$ \\
\hline
\end{tabular}

Tabela 3. Analiza SWOT kawiarni tworzonej pod własną marką

\begin{tabular}{|c|c|}
\hline \multicolumn{2}{|c|}{ Uwarunkowania wewnętrzne } \\
\hline Mocne strony & Słabe strony \\
\hline - swoboda w kreowaniu & - duża konkurencja lokali \\
marki, marży, oferty & sieciowych, \\
- możliwość uzyskania & - wysokie nakłady oraz \\
dofinansowania inwestycji & długi czas potrzebny na \\
& wypromowanie kawiarni \\
\hline
\end{tabular}

\begin{tabular}{|c|c|}
\hline \multicolumn{2}{|c|}{ Uwarunkowania zewnętrzne } \\
\hline \multicolumn{1}{|c|}{ Szanse } & Zagrożenia \\
\hline - możliwość dopasowania & $-100 \%$ ryzyko ponoszonych \\
inwestycji i jej charakteru & strat \\
obiektu do wymagań grupy & - możliwość nie osiągnięcia \\
docelowej i potencjalnych & rentowności przy braku \\
klientów & znajomości branży \\
- pełna możliwość reakcji & - zagrożenie nietrafienia \\
na zmieniający się rynek & w gusty klientów \\
i warunki sprzedaży & - na rynku dominują \\
- możliwość brania udziału & kawiarnie sieciowe \\
w eventach, akcjach, & \\
wydarzeniach & \\
- możliwość szybkiej & \\
redukcji kosztów & \\
\hline
\end{tabular}

Źródło: Opracowanie własne.

Tabela 4. Analiza SWOT kawiarni będącej franczyzą A. Blikle

\begin{tabular}{|c|c|}
\hline \multicolumn{2}{|c|}{ Uwarunkowania wewnętrzne } \\
\hline Mocne strony & \begin{tabular}{|c|} 
Słabe strony \\
\end{tabular} \\
\hline $\begin{array}{l}\text { - możliwość wsparcia } \\
\text { sprzedaży poprzez znaną } \\
\text { markę } \\
\text { - profesjonalny marketing } \\
\text { - pozyskanie know-how } \\
\text { - ustandaryzowana jakość } \\
\text { produktów } \\
\text { - wsparcie franczyzodawcy } \\
\text { - możliwość negocjacji } \\
\text { warunków najmu }\end{array}$ & $\begin{array}{l}\text { - wysoki nakład finansowy } \\
\text { związany z adaptacją } \\
\text { i standaryzowaniem lokalu } \\
\text { - brak możliwości negocjacji } \\
\text { umowy franczyzowej } \\
\text { i najmu } \\
\text { - kary za niestosowanie się } \\
\text { do standardów } \\
\text { - brak możliwości ingerencji } \\
\text { w ofertę }\end{array}$ \\
\hline \multicolumn{2}{|c|}{ Uwarunkowania zewnętrzne } \\
\hline Szanse & \begin{tabular}{|r|} 
Zagrożenia \\
\end{tabular} \\
\hline $\begin{array}{l}\text { - sprzedaż produktów pod } \\
\text { znaną marką istniejącą od } \\
\text { ponad140 lat na rynku }\end{array}$ & $\begin{array}{l}\text { - spadek jakości oraz sprze- } \\
\text { daży całej sieci ma wpływ } \\
\text { na sprzedaż pojedynczego } \\
\text { franczyzobiorcy } \\
\text { - brak możliwości reakcji } \\
\text { na zmieniający się rynek } \\
\text { i sprzedaż }\end{array}$ \\
\hline
\end{tabular}

Źródło: Opracowanie własne.

Tabela 5. Analiza SWOT kawiarni So!Coffee prowadzonej $\mathrm{w}$ formie ajencji

\begin{tabular}{|c|l|}
\hline \multicolumn{2}{|c|}{ Uwarunkowania wewnętrzne } \\
\hline Mocne strony & \multicolumn{1}{|c|}{ Słabe strony } \\
\hline - rozpoznawalna marka z do- & - niskie wynagrodzenie, \\
brą opinią & uzależnione od sprzedaży \\
- niskie nakłady finansowe dla & - liczne kontrole, audyty \\
uruchomienia działalności & - kary za niespełnienie \\
- profesjonalny marketing i re- & warunków umowy \\
gularne wsparcie w sprzedaży & agencyjnej \\
- programy motywacyjne dla & \\
sprzedawców & \\
- wsparcie w pokrywaniu & \\
strat i braków & \\
- niskie koszty prowadzenia & \\
działalności & \\
\hline
\end{tabular}




\begin{tabular}{|c|l|}
\hline \multicolumn{2}{|c|}{ External conditions } \\
\hline \multicolumn{1}{|c|}{ Opportunities } & \multicolumn{1}{c|}{ Threats } \\
\hline $\begin{array}{l}\text { - a well-known brand after } \\
\text { the rebranding process }\end{array}$ & $\begin{array}{l}\text { - decrease in the quality and } \\
\text { sales of the entire network } \\
\text { has an impact on the sales } \\
\text { of an individual agent } \\
\text { - no possibility of reacting to } \\
\text { the changing market and } \\
\text { sales } \\
\text { - the possibility of losing } \\
\\
\text { the café without the notice } \\
\text { period in the agency } \\
\text { agreement }\end{array}$ \\
\hline
\end{tabular}

Source: own study.

\section{Planned investment expenditures}

The financial plan prepared for two locations and three business models includes: planned revenues and costs, the amount of profit or loss from operations, cash flows, assumed financial ratios, and projected outlays.

The investor's main goal is to create a gastronomic and service facility that brings long-term profit and ensure its economic stability. The investment expenditures for setting up a café vary depending on the location and business model that will be selected. The forecasted capital expenditures are presented in tables 6 and 7 .

The value of the net investment in the least demanding project - the agency of So!Coffee - starts from PLN 12 thousand. It is important in this case that the value of the investment is fixed and does not depend on the location. The net investment expenditure in the case of opening a café under its own brand or in franchise ranges from over PLN 100 thousand to almost PLN 400 thousand.

\begin{tabular}{|l|l|}
\hline \multicolumn{2}{|c|}{ Uwarunkowania zewnętrzne } \\
\hline \multicolumn{1}{|c|}{ Szanse } & \multicolumn{1}{c|}{ Zagrożenia } \\
\hline -znana rozpoznawalna & - spadek jakości oraz \\
marka po procesie & sprzedaży całej sieci \\
rebrandingu & ma wpływ na sprzedaż \\
& pojedynczego ajenta \\
& - brak możliwości reakcji \\
& na zmieniający się rynek \\
& i sprzedaż \\
& - możliwość utraty kawiarni \\
& bez zachowania okresu \\
& wypowiedzenia umowy \\
& agencyjnej \\
\hline
\end{tabular}

Źródło: Opracowanie własne.

\section{Planowane nakłady inwestycyjne}

Plan finansowy sporządzony dla dwóch lokalizacji i trzech modeli biznesowych obejmuje: planowane przychody oraz koszty, wysokość zysku lub straty z działalności, przepływy gotówki, zakładane wskaźniki finansowe, prognozowane nakłady.

Głównym celem inwestora jest doprowadzenie do powstania lokalu gastronomiczno- usługowego przynoszącego długotrwały zysk oraz zapewnienie mu stabilności ekonomicznej. Nakłady inwestycyjne na uruchomienie kawiarni różnią się $\mathrm{w}$ zależności od lokalizacji oraz modelu biznesowego jaki zostanie wybrany. Prognozowane nakłady inwestycyjne zostały przedstawione w tabeli nr 6 i 7.

Wartość inwestycji netto w najmniej wymagającym projekcie - ajencji So!Coffee - zaczyna się już od 12 tys. zł. Ważny w tym przypadku jest fakt, że wartość inwestycji jest stała i nie zależy od lokalizacji. Nakład inwestycyjny netto w przypadku otwarcia kawiarni pod własną marką lub we franczyzie sięga od ponad 100 tys. zł do prawie 400 tys. zł.

Table 6. Forecasted capital expenditures - café in the Arkadia Shopping Centre

Tabela 6. Prognozowane nakłady inwestycyjne - kawiarnia w CH Arkadia

\begin{tabular}{|l|c|c|c|}
\hline \multicolumn{1}{|c|}{ Types of expenditures / Rodzaje nakładów } & $\begin{array}{c}\text { Private } \\
\text { (own brand) / } \\
\text { Własna marka }\end{array}$ & $\begin{array}{c}\text { Franchise } \\
\text { A. Blikle / } \\
\text { Franczyza } \\
\text { A.Blikle }\end{array}$ & $\begin{array}{c}\text { The agency of } \\
\text { So!Coffee / } \\
\text { Ajencja } \\
\text { So!Coffee }\end{array}$ \\
\hline Adaptation of the premises / Adaptacja lokalu & $\mathbf{6 3 0 0 0}$ & $\mathbf{1 1 0 0 0 0}$ & - \\
\hline Project / Projekt & 10000 & 25000 & - \\
\hline Construction works and materials / Materiały i prace budowlane & 36000 & 58000 & - \\
\hline Mobile furniture / Meble ruchome & 12000 & 20000 & - \\
\hline Lighting and other / Oświetlenie i inne & 5000 & 7000 & - \\
\hline Equipment of the facility / Wyposażenie lokalu & $\mathbf{8 0 0 0 0}$ & $\mathbf{1 4 0 0 0 0}$ & - \\
\hline Catering equipment / Urządzenia gastronomiczne & 70000 & 120000 & - \\
\hline Other equipment / Wyposażenie inne & 10000 & 20000 & - \\
\hline Fees and deposits / Opłaty i kaucje & $\mathbf{9 0 0 0 0}$ & $\mathbf{9 0 0 0 0}$ & $\mathbf{1 2 0 0 0}$ \\
\hline Initial payment (license fee) / Opłata wstępna (licencyjna) & - & 30000 & - \\
\hline Net investment value / Wartość inwestycji netto & $\mathbf{2 3 3 0 0 0}$ & $\mathbf{3 4 0 0 0 0}$ & $\mathbf{1 2 0 0 0}$ \\
\hline Gross investment value / Wartość inwestycji brutto & $\mathbf{2 6 3 5 9 0}$ & $\mathbf{4 3 2 \mathbf { 1 0 0 }}$ & $\mathbf{1 4 7 6 0}$ \\
\hline
\end{tabular}

Source: Own study based on materials provided by A. Blikle and So!Coffee.

Źródło: Opracowanie własne na podstawie materiałów udostępnionych przez firmy A.Blikle oraz So!Coffee. 
Table 7. Forecasted capital expenditures - café at the Nowy Świat street

Tabela 7. Prognozowane nakłady inwestycyjne - kawiarnia przy ul. Nowy Świat

\begin{tabular}{|c|c|c|c|}
\hline Types of expenditures / Rodzaje nakładów & $\begin{array}{c}\text { Private } \\
\text { (own brand) / } \\
\text { Własna marka }\end{array}$ & $\begin{array}{c}\text { Franchise } \\
\text { A. Blikle / } \\
\text { Franczyza } \\
\text { A.Blikle }\end{array}$ & $\begin{array}{c}\text { The agency of } \\
\text { So!Coffee / } \\
\text { Ajencja } \\
\text { So!Coffee }\end{array}$ \\
\hline Adaptation of the premises / Adaptacja lokalu & 37000 & 75000 & - \\
\hline Project / Projekt & 5000 & 10000 & - \\
\hline Construction works and materials / Materiały i prace budowlane & 21000 & 38000 & - \\
\hline Mobile furniture / Meble ruchome & 6000 & 20000 & - \\
\hline Lighting and other / Oświetlenie i inne & 5000 & 7000 & - \\
\hline Equipment of the facility / Wyposażenie lokalu & 48000 & 115000 & - \\
\hline Catering equipment / Urządzenia gastronomiczne & 40000 & 100000 & - \\
\hline Other equipment / Wyposażenie inne & 8000 & 15000 & - \\
\hline Fees and deposits / Opłaty i kaucje & 60000 & 60000 & 12000 \\
\hline Initial payment (license fee) / Opłata wstępna (licencyjna) & - & 30000 & - \\
\hline Net investment value / Wartość inwestycji netto & 145000 & 280000 & 12000 \\
\hline Gross investment value / Wartość inwestycji brutto & 155350 & 321400 & 14760 \\
\hline
\end{tabular}

Source: Own study based on materials provided by A. Blikle and So!Coffee.

Źródło: Opracowanie własne na podstawie materiałów udostępnionych przez firmy A.Blikle oraz So!Coffee.

Starting cooperation with the brand So!Coffee on terms of an agency, the only financial cost of the investor that he/she is able to cover with his/her own capital is a security deposit for a cooperation agreement in the amount of PLN 14760 gross. In the other two cases, the cost of opening a café will be much higher. The highest financial outlay (PLN 432,1 thousand) awaits the investor when opening the franchise of the A. Blikle café in the Arkadia Shopping Centre. Launch of a café under the same brand at Nowy Świat street will be a cheaper by more than PLN 100 000. This results from the fact that the shopping centre is much more demanding towards its tenants in the scope of the quality of materials, attractiveness and uniqueness of the concept. The least demanding project in terms of the amount of investment expenditure will be the launch of a café under its own brand at the Nowy Świat street. We can economise not only on the adaptation of the premises, but also on the equipment by using, for example, used equipment. It shouldn't be done in the case of a franchise A. Blikle. The costs related to charges which are connected with the setup of a business, insurance of premises, execution of a lease agreement and the employment of personnel should not be overlooked.

\section{Forecasted revenues and costs of business models}

The cost and benefit analysis method and the discount method determining the internal rate of return were used when conducting the financial analysis of the investment project. The work presents selected elements of these analyses that illustrate the condition of particular business models in the first and fifth year of operation. By forecasting revenues from investments, a number of assumptions were made concerning the average daily number of clients $(250$ persons in the franchise branch A. Blikle and in the So!Coffee agency and 175 people in own brand), the
Rozpoczynając współprace z marką So!Coffee na zasadach ajencji jedyny nakład finansowy inwestora, który jest w stanie pokryć kapitałem własnym, to kaucja zabezpieczająca umowę współpracy w wysokości 14760 zł brutto. W dwóch pozostałych przypadkach koszt otwarcia kawiarni będzie znacznie większy. Największy nakład finansowy (432,1 tys. zł) czeka inwestora w momencie otwarcia franczyzy kawiarni A. Blikle w CH Arkadia. Uruchomienie kawiarni pod tą samą marką przy ul. Nowy Świat będzie już tańsze o ponad 100 tys. Wynika to z faktu, ze centrum handlowe jest znacznie bardziej wymagające wobec swoich najemców co do jakości materiałów, atrakcyjności i wyjątkowości koncepcji. Najmniej wymagającym projektem pod względem wysokości nakładu inwestycyjnego będzie uruchomienie kawiarni pod własną marką przy ul. Nowy Świat. Możemy tak zaoszczędzić nie tylko na adaptacji lokalu, ale również na wyposażeniu korzystając np. z używanego sprzętu. Na to nie można sobie pozwolić w przypadku franczyzy A. Blikle. Nie należy również zapominać o kosztach związanych z opłatami związanymi z założeniem działalności gospodarczej, ubezpieczeniem lokalu, podpisaniem umowy najmu lokalu oraz zatrudnieniem personelu.

\section{Prognozowane przychody i koszty modeli bizne- sowych}

Przy prowadzeniu analizy finansowej przedsięwzięcia inwestycyjnego wykorzystano metodę analizy kosztów i korzyści oraz metodę dyskontową określająca wewnętrzna stopę zwrotu. W pracy przedstawiono wybrane elementy tych analiz ilustrujące stan $\mathrm{w}$ pierwszym i piątym roku funkcjonowania poszczególnych modeli biznesowych. Przy prognozowaniu przychodów z inwestycji przyjęto szereg założeń dotyczących średniej dziennej liczby klientów (po 250 osób w placówce franczyzowej A. 
annual sales growth (2\% in a network branch and $5 \%$ in a branch under own name), the amount of margins and remuneration of a commission agent - $13 \%$ on the sale of coffee and $11 \%$ on all other products). It was assumed that the margin on products will be diversified within $40-80 \%$ in the scope of particular business models and different in relation to selected types of products. It is foreseen that in the sales structure the coffee and beverages will vahe about $60 \%$ share, cakes and layer cakes $25 \%$.

Depreciation costs will range from PLN 12700 per year by running own brand at Nowy Świat up to PLN 35000 in the case of franchise A. Blikle in the Arkadia Shopping Centre. It was assumed that depreciation of commercial kitchen equipment will amount to $20 \%$ and other fixed assets $10 \%$ per annum. Operating costs consist of insurance, social security, accountancy, logistics and manufacturing costs. Furthermore, the consumption costs of materials, energy, telephone and internet are also the part of such costs. The level of costs and revenues for various business models in the suggested locations is shown in Table 8.
Blikle i ajencji So!Coffee oraz 175 osób w przypadku własnej marki), rocznego wzrostu sprzedaży (2\% w placówce sieciowej i 5\% w palcówce pod własna marką), wysokości marż i wynagrodzeń ajenta - 13\% przy sprzedaży kawy i $11 \%$ od pozostałych produktów). Założono, że marża na produktach będzie zróżnicowana w granicach $40-80 \%$ w poszczególnych modelach biznesowych i różna $w$ odniesieniu do poszczególnych rodzajów produktów. Przewidziano, że w strukturze sprzedaży udział kawy i napojów wyniesie około $60 \%$, ciast i tor tów $25 \%$ :

Koszty amortyzacji będą się kształtować w granicach od 12700 zł rocznie przy prowadzeniu marki własnej na Nowym Świecie do 35000 zł przy formie franczyzy A. Blikle w C.H. Arkadia. Przyjęto, że amortyzacja na urzadzenia gastronomiczne wyniesie $20 \%$ a na inne środki trwałe $10 \%$ rocznie. Na koszty operacyjne składają się koszty ubezpieczenia, zużycia materiałów i energii, telefonu, internetu, koszt logistyki, produkcji, prowadzenia księgowości oraz ZUS. Poziom kosztów i zysków dla różnych modeli biznesowych w proponowanych lokalizacjach przedstawia tabela 8 .

Table 8. Forecasted revenues, costs and profits of various business models of services provided by cafés in the first year of their operation expressed in PLN

Tabela 8. Prognozowane przychody, koszty i zyski różnych modeli biznesowych prowadzenia usług kawiarnianych w pierwszym roku działalności w zł

\begin{tabular}{|c|c|c|c|}
\hline \multirow[b]{2}{*}{ Specification / Wyszczególnienie } & \multicolumn{3}{|c|}{$\begin{array}{l}\text { The model of running services / } \\
\text { Model prowadzenia usług }\end{array}$} \\
\hline & $\begin{array}{c}\text { Franchise } \\
\text { A. Blikle / } \\
\text { Franczyza } \\
\text { A. Blikle } \\
\end{array}$ & $\begin{array}{c}\text { Dealership } \\
\text { So!Coffee / } \\
\text { Ajencja So!Coffee }\end{array}$ & $\begin{array}{c}\text { Own brand / } \\
\text { Własna marka }\end{array}$ \\
\hline $\begin{array}{l}\text { The assumed number of receipts / } \\
\text { Zakładana liczba paragonów }\end{array}$ & 90000 & 90000 & 63000 \\
\hline Turnover/ Obrót & 1800000 & 1800000 & 1260000 \\
\hline Revenues from sales / Przychód ze sprzedaży & 1071000 & 219600 & 875700 \\
\hline \multicolumn{4}{|c|}{ Costs and profits for the location in the Arkadia Shopping Centre / Koszty i zyski dla lokalizacji w C.H. Arkadia } \\
\hline Total amount of operating costs / Koszty operacyjne razem & 742213 & 149508 & 717613 \\
\hline Result of operating activities / Wynik z działalności operacyjnej & 328787 & 70092 & 158087 \\
\hline Costs of financial activities / Koszty działalności finansowej & 22068 & - & 10870 \\
\hline Gross profit / Zysk brutto & 306719 & 70092 & 147217 \\
\hline Income tax / Podatek dochodowy & 58227 & 13317 & $27973 ?$ \\
\hline Net profit / Zysk netto & 248424 & 56775 & 119246 \\
\hline \multicolumn{4}{|c|}{ Costs and profits for the location at the Nowy Świat street / Koszty i zyski dla lokalizacji przy ul. Nowy Świat } \\
\hline Total amount of operating costs / Koszty operacyjne razem & 603217 & 184332 & 585917 \\
\hline Result of operating activities / Wynik z działalności operacyjnej & 467783 & 35268 & 289783 \\
\hline Costs of financial activities / Koszty działalności finansowej & 14712 & - & 3684 \\
\hline Gross profit / Zysk brutto & 453071 & 35268 & 286075 \\
\hline Income tax / Podatek dochodowy & 86083 & 6701 & 54359 \\
\hline Net profit / Zysk netto & 366988 & 28567 & 231740 \\
\hline
\end{tabular}

Source: Own study.

Źródło: Opracowanie własne.

Services provided by cafés are characterised by the seasonal nature of demand. However, in the case of the café situated in the shopping centre such demand will be completely different in comparison to the street café . In the area at Nowy Świat street, the demand increases in the summer, and in the Arkadia Shopping
Usługi kawiarniane charakteryzują się sezonowością popytu. Sezonowość kawiarni w centrum handlowym będzie zupełnie inna niż tej przy ulicy. Na Nowym Świecie popyt zwiększa się latem, a w $\mathrm{CH}$ Arkadia na jesieni. Na podstawie średnich miesięcznych przychodów obliczono również wskaź- 
Centre in the autumn. On the basis of average monthly revenues, two indicators were also calculated. The first one informs about the period when revenues will be higher than costs for the first time. The second one includes information about the period in which the return on the capital employed will occur. In all assumed business options, revenues exceed the costs in the first month. The shortest period of the return on investment will be achieved in the case of running the dealership So!Coffee both at the Arkadia Shopping Centre and at Nowy Świat street. The investor should take into account the longest period of return on investment by running the brand in the form of his own franchise café at the Arkadia Shopping Centre. Opening a café at the Nowy Świat street we can expect a return on investment from the first year. The return on the investment spent on own brand at the Arkadia Shopping Centre will take 19 months, and in the case of the franchise café it will last 15 months. The highest level of profit in the fifth year of operation will be reached by franchise café A. Blikle at the Nowy Świat street. High gross profit will also be generated by own brand café at this street. Tables 9 and 10 present forecasts of the sales revenues, operating costs related to business and gross profits incurred in the fifth year of café 's operation. nik informujący o czasie, w którym po raz pierwszy przychody będą wyższe niż koszty oraz wskaźnik informujący o czasie, w którym nastąpi zwrot zainwestowanego kapitału. We wszystkich zakładanych opcjach biznesowych przychody już w pierwszym miesiącu przewyższają koszty. Najkrótszy okres zwrotu nakładów inwestycyjnych zostanie osiągnięty w przypadku prowadzenia ajencji kawiarni So!Coffee zarówno w CH Arkadii jaki i na Nowym Świecie. Najdłuższy okres zwrotu z inwestycji czeka inwestora przy prowadzeniu marki własnej kawiarni franczyzowej w CH Arkadia. Otwierając kawiarnię przy ul. Nowy Świat możemy liczyć na zwrot z inwestycji już w pierwszym roku. Zwrot nakładów zainwestowanych w markę własną w CH Arkadia potrwa 19 miesięcy, a w kawiarnię franczyzową 15 miesięcy. Najwyższy poziom zysku w piątym roku funkcjonowania osiagnie kawiarnia franczyzowa A. Blikle na ul. Nowy Swiat. Wysoki zysk brutto zapewni także kawiarnia własna przy tej ulicy. Tabele 9 i 10 przedstawiają prognozy przychodów ze sprzedaży, koszty operacyjne działalności oraz zyski brutto poniesione w piątym roku funkcjonowania kawiarni.

Table 9. Forecasted revenues, costs and profits as well as return on capital expenditures in the fifth year of the operation of the café expressed in PLN

Tabela 9. Prognozowane przychody, koszty i zyski oraz zwrot nakładów inwestycyjnych w piątym roku funkcjonowania kawiarni w zł

\begin{tabular}{|c|c|c|c|}
\hline Specification / Wyszczególnienie & $\begin{array}{c}\text { Franchise } \\
\text { A. Blikle / } \\
\text { Franczyza } \\
\text { A. Blikle } \\
\end{array}$ & $\begin{array}{c}\text { Dealership } \\
\text { So!Coffee / } \\
\text { Ajencja So!Coffee }\end{array}$ & $\begin{array}{l}\text { Own brand / } \\
\text { Własna marka }\end{array}$ \\
\hline \multicolumn{4}{|c|}{ The location of a café at the Arkadia Shopping Centre / Lokalizacja kawiarni w CH Arkadia } \\
\hline Revenues from sales / Przychody ze sprzedaży & 1159285 & 237702 & 1064419 \\
\hline Operating costs / Koszty operacyjne & 742213 & 149508 & 717613 \\
\hline Result on operating activities / Wynik na działalności operacyjnej & 417072 & - & 346806 \\
\hline Costs of financial activities / Koszty z działalności finansowej & 8784 & - & 4326 \\
\hline Gross profit / Zysk brutto & 408288 & 88194 & 342480 \\
\hline $\begin{array}{l}\text { Forecasted profitability EBITDA / } \\
\text { Prognozowana rentowność EBITDA }\end{array}$ & 452872 & 71437 & 367106 \\
\hline \multicolumn{4}{|c|}{ Location of a café at the Nowy Świat street / Lokalizacja kawiarni przy ul. Nowy Świat } \\
\hline Revenues from sales / Przychody ze sprzedaży & 1159285 & 237700 & 1064419 \\
\hline Operating costs / Koszty operacyjne & 603217 & 184332 & 585917 \\
\hline Result on operating activities / Wynik na działalności operacyjnej & 556068 & - & 478502 \\
\hline Costs of financial activities / Koszty z działalności finansowej & 5856 & - & 1470 \\
\hline Gross profit / Zysk brutto & 550212 & 53368 & 477032 \\
\hline $\begin{array}{l}\text { Forecasted profitability EBITDA / } \\
\text { Prognozowana rentowność EBITDA }\end{array}$ & 444572 & 43230 & 490202 \\
\hline
\end{tabular}

Source: own study.

Źródło: Opracowanie własne.

In the fifth year of operation, the highest operating profit before tax (EBIT) [Earnings Before Income Tax] can be expected by an investor who decided to run a franchise of café A. Blikle at the Nowy Świat
W piątym roku działalności najwyższego zysku operacyjnego przed opodatkowaniem (EBIT) może spodziewać się inwestor, który zdecydował się na prowadzenie franczyzy kawiarni A. Blikle przy ul. 
street. However, if the depreciation cost will be deducted from the operating profit before tax, the achieved ratio indicates that the highest profitability (EBITDA) will reach own brand café at Nowy Świat street (table 9).
Nowy Świat. Jednak gdy od zysku operacyjnego przed opodatkowaniem odejmiemy koszt amortyzacji osiągnięty wskaźnik wskazuje, że najwyższą rentowność (EBITDA) osiągnie kawiarnia własna na Nowym Świcie (tabela 9).

Table 10. Forecasted 5-year return on sales indicators (ROS) expressed in \%

Tabela 10. Prognozowane 5-letnie wskaźniki rentowności na sprzedaży ROS w \%

\begin{tabular}{|l|c|c|c|c|c|}
\hline \multicolumn{1}{|c|}{$\begin{array}{c}\text { Business model / } \\
\text { Model biznesowy }\end{array}$} & $\begin{array}{c}\text { 1st year / } \\
\text { rok 1 }\end{array}$ & $\begin{array}{c}\text { 2nd year / } \\
\text { rok 2 }\end{array}$ & $\begin{array}{c}\text { 3rd year / } \\
\text { rok 3 }\end{array}$ & $\begin{array}{c}\text { 4th year / } \\
\text { rok 4 }\end{array}$ & $\begin{array}{c}\text { 5th year / } \\
\text { rok 4 }\end{array}$ \\
\hline $\begin{array}{l}\text { franchise A. Blikle The Arkadia Shopping Centre / } \\
\text { franczyza A. Blikle Arkadia }\end{array}$ & 23 & 25 & 26 & 27 & 29 \\
\hline $\begin{array}{l}\text { franchise A. Blikle The Nowy Świat street / } \\
\text { franczyza A. Blikle Nowy Świat }\end{array}$ & 34 & 36 & 37 & 38 & 38 \\
\hline $\begin{array}{l}\text { dealership So!Coffee The Arkadia Shopping Centre / } \\
\text { ajencja So!Coffee Arkadia }\end{array}$ & 26 & 27 & 28 & 29 & 30 \\
\hline $\begin{array}{l}\text { dealership So!Coffee The Nowy Świat street / } \\
\text { ajencja So!Coffee Nowy Świat }\end{array}$ & 13 & 14 & 16 & 17 & 18 \\
\hline $\begin{array}{l}\text { own brand The Arkadia Shopping Centre / } \\
\text { marka własna Arkadia }\end{array}$ & 17 & 17 & 20 & 23 & 26 \\
\hline $\begin{array}{l}\text { own brand at The Nowy Świat street / } \\
\text { marka własna Nowy Świat }\end{array}$ & 26 & 29 & 32 & 34 & 36 \\
\hline
\end{tabular}

Source: Own study.

Źródło: Opracowanie własne.

The highest return on sales (ROS), both in the first and the fifth year of operation, will be reached by the franchise café A. Blikle at the Nowy Świat Street (table $10)$. The second place will go to own brand café at the Nowy Świat Street. The highest efficiency of equity will be achieved by the commission agent So!Coffee. However, it should be remembered that in this case it does not involve the possibility to obtain the highest financial surplus. It depends to a large extent on the amount of equity invested, which varies in all cases. The highest rate of return on investment expenditure will also be achieved by the So!Coffee café. Its capital, however, is much lower than in the other cases.

\section{Conclusion}

1. Among the cafés operating on the market, we distinguish network cafés that exist under one brand and individual units - independent cafés. The network outlets in Poland constitute $15 \%$ of the total number of cafés, and carry out $34 \%$ of sales on the market, the remaining $66 \%$ are carried out by independent branches. Recognition of the café brand determines to a large extent on the customer who visits it. Some choose a well-known and proven brand, others opt for individuality and avoid mass media. Cafés cease to be a place where only the need for caffeine is met. They are becoming more and more popular places for social and business meetings, therefore analysts assume the growth of both individual and network café market.

2. The business models available on the Polish cafeteria market give the investor a wide range of investment options that differ not only in organizational and legal terms butalso in financial
Zarówno w pierwszym jak i piątym roku działalności najwyższą rentowność na sprzedaży (ROS) osiągnie kawiarnia franczyzy A. Blikle na ul. Nowy Świat (tabela 10). Na drugim miejscu znajdzie się kawiarnia własna na ul. Nowy Świat. Najwyższa efektywność kapitału własnego osiągnie natomiast ajent So!Coffee. Należy jednak pamiętać, że w tym przypadku nie wiąże się to z możliwością uzyskania najwyższej nadwyżki finansowej. Uzależniona jest ona w dużym stopniu od kwoty zainwestowanego kapitału własnego, która we wszystkich przypadkach jest różna. Również najwyższą stopę zwrotu nakładów inwestycyjnych osiągnie ajent So!Coffee. Jego kapitał jest jednak znacznie niższy niż w pozostałych przypadkach.

\section{Wnioski}

1. Wśród kawiarni funkcjonujących na rynku wyróżniamy kawiarnie sieciowe, które występują pod jedna marka oraz pojedyncze jednostki kawiarnie niezależne. Placówki sieciowe w Polsce stanowią $15 \%$ liczby kawiarni, a realizują $34 \%$ sprzedaży na rynku, pozostałe $66 \%$ realizują placówki niezależne. Rozpoznawalność marki kawiarni decyduje w znacznym stopniu o kliencie, który ją odwiedza. Jedni wybierają znaną i sprawdzoną markę, inni stawiają na indywidualność i unikają masowości. Kawiarnie przestają być miejscem, w którym jedynie zaspokajana jest potrzeba na kofeinę. Stają się coraz popularniejszymi miejscami do spotkań towarzyskich i biznesowych $\mathrm{w}$ związku z czym analitycy zakładają wzrost rynku, zarówno indywidualnego jak i sieciowego.

2. Dostępne na polskim rynku kawiarnianym modele prowadzenia biznesu dają inwestorowi szeroki wachlarz opcji inwestycyjnych, które różnią się 
results. The choice of a business model depends on the investor's expectations, its propeneness to risk and the location of the object. In the process of making investment decisions, it is necessary to know about the unit itself and about the environment and competition. An indispensable element in this type of investments is the creation of a good business plan based on real data and information coming from the market and a good selection of location.

3. When choosing a location in shopping centres, it should be taken into account that the network cafes will operate better and new brands should start from the premises located on the main streets. The investor's tendency to take risks is also important. Individuals who prefer lower but more reliable income from high profits and high risk should choose an agency. Choosing a franchise or a café model under own brand creates the possibility of higher profits, but these are ventures at high risk.

4. Many factors influence the company's financial results. The basic issue is selection of abusiness model and the adopted assortment of sales. The highest margins can be achieved by an investor deciding to work under his/her own brand. One can reach the margins on coffee even up to $80 \%$. Also in this case, the investor has the largest impact on the sales structure. Opening cafés in a well-known chain, we will achieve lower margins on products, however, in the first year of activity we can count on higher profits due to more visitors. Creating a new brand requires much more commitment and positive marketing.

5. The structure of revenues and costs, as well as the level of investment outlays, apart from the business model, are strongly influenced by the location. When opening a franchise or own café in the Arkadia Shopping Centre, an entrepreneur has to take into account higher expenditures than in the case of a café at the Nowy Świat street by PLN 60 - 90 thousand. It will also not achieve return on investment in the first year of activity. The coffee shop at the Arkadia Shopping Centre is also more expensive to maintain than the one at the Nowy Świat street. If we run a café on the street, we can count on higher profits in the next few years. Both locations differ in seasonality of demand, at the Nowy Świat street it will be intensified in the summer, while in the Arkadia Shopping Centre in the autumn and winter. The owner of a street café can freely manage the opening hours and working hours of the café, which is not possible with the shopping centre. However, the investor bears a higher risk by opening a street café . This risk is not borne by the owner of the café in the shopping centre.

6 . The format and manner in which the café will operate depends on the individual competences and preferences of the investor. It should be emphasized that success also depends on the investor's commitment, ambition and diligence. od siebie nie tylko pod względem organizacyjno -prawnym ale również wynikami finansowymi. Wybór modelu biznesowego zależy od oczekiwań inwestora, jego skłonności do ryzyka oraz lokalizacji obiektu. W procesie podejmowania decyzji inwestycyjnych niezbędna jest wiedza o samej jednostce oraz o otoczeniu i konkurencji. Niezbędnym elementem przy inwestycjach tego typu jest stworzenie dobrego planu biznesowego opartego, na realnych danych i informacjach pochodzących z rynku oraz trafny wybór lokalizacji.

3. Przy wyborze lokalizacji $w$ centrach handlowych należy uwzględnić to, że lepiej poradzą sobie kawiarnie sieciowe, nowe marki powinny natomiast zacząć od lokali znajdujących się przy głównych ulicach. Ważna jest również skłonność inwestora do ryzyka. Osoby, które od wysokich zysków i dużego ryzyka wolą niższe, ale pewniejsze dochody powinny wybrać ajencję. Wybór modelu franczyzy lub kawiarni pod własną marką stwarza możliwość wyższych zysków, ale są to przedsięwzięcia zagrożone wysokim ryzykiem.

4. Na wyniki finansowe firmy wpływ ma szereg czynników. Kwestią podstawową jest wybór modelu biznesowego i przyjęty asortyment sprzedaży. Najwyższe marże może osiągnąć inwestor decydujący się na własną markę. Na kawie może on osiągnąć marże $\mathrm{w}$ wysokości nawet $80 \%$. Również w tym przypadku inwestor ma największy wpływ na strukturę sprzedaży. Otwierając kawiarnie w znanej sieci osiągniemy niższe marże na produktach, jednak możemy w pierwszym roku działalności liczyć na wyższe zyski w związku z większą liczbą odwiedzających. Stworzenie nowej marki wymaga dużo większego zaangażowania i pozytywnego marketingu.

5. Na strukture przychodów i kosztów oraz na wysokość nakładów inwestycyjnych oprócz modelu prowadzenia działalności duży wpływ ma lokalizacja. Otwierając kawiarnię franczyzowa lub własną w C.H. Arkadia przedsiębiorca musi liczyć się z nakładami wyższymi niż w przypadku kawiarni przy ul. Nowy Swiat o 60 - 90 tys. zł. Nie osiągnie on również zwrotu z inwestycji w pierwszym roku działalności. Kawiarnia w C.H Arkadia jest również droższa w utrzymaniu niż ta przy, ul. Nowy Świat. Prowadząc kawiarnię przy ulicy możemy liczyć na wyższe zyski w perspektywie kilkuletniej. Obie lokalizacje różnią się sezonowością popytu, przy ul. Nowy Świat wzmożony ruch będzie latem, natomiast w CH Arkadia jesienią i zimą. Właściciel kawiarni prowadzonej przy ulicy może swobodnie zarządzać godzinami otwarcia i czasu pracy kawiarni, czego nie umożliwia centrum handlowe. Inwestor ponosi jednak wyższe ryzyko otwierając kawiarnię przy ulicy. Tego ryzyka nie ponosi właściciel kawiarni w centrum handlowym.

6. Format i sposób, w jakim będzie działała kawiarnia zależy od indywidualnych kompetencji i preferencji inwestora. Należy podkreślić fakt, że również sukces zależy od jego zaangażowania, ambicji i pracowitości. 


\section{References/ Literatura:}

1. Bartkowicz J. (2015), Wybrane zachowania konsumentów na rynku kawy naturalnej. Handel Wewnętrzny, 2(345), s. 45-57.

2. Bednarski L. (2011), Analiza ekonomiczno-finansowa przedsiębiorstw. Oficyna Wydawnicza Politechniki Warszawskiej, Warszawa.

3. Cieślik J. (2006), Przedsiębiorczość dla ambitnych. Jak uruchomić własny biznes. Wydawnictwa Akademickie i Profesjonalne, Warszawa.

4. Dobrołowicz W. (2012), Inteligencja intuicyjna a sukces $w$ biznesie. Studia Ekonomiczne, Zeszyty Naukowe Uniwersytetu Ekonomicznego w Katowicach, nr 114, s. 115-125.

5. Gabrusewicz W. (2005), Podstawy analizy finansowej. PWE, Warszawa.

6. Gabrusewicz W. (2014), Analiza finansowa przedsiębiorstwa teoria i zastosowanie. PWE, Warszawa.

7. Kraśnicka T. (2002), Koncepcja rozwoju przedsiębiorczości ekonomicznej i pozaekonomicznej. Prace Naukowe - Akademia Ekonomiczna im. Karola Adamieckiego, Katowice 2007

8. Łukasik G. (2006), Analiza Finansowa w procesie decyzyjnym współczesnego przedsiębiorstwa. Wydawnictwo Uniwersytetu Ekonomicznego w Katowicach, Katowice.

9. Matusiak K. B., Mażewska M. (2005), Pierwsza praca - pierwszy biznes, vademecum przedsiębiorczości. Biblioteka Rynku Pracy, MGiP Warszawa.

10. Matusiak K. B. (2006), Rozwój systemów wsparcia przedsiębiorczości - przesłanki, polityka i instytucje. Wydawnictwo ITE-PIB Łódź.

11. Matusiak K. (2007), Systemy wsparcia przedsiębiorczości i procesów innowacyjnych. Zeszyty Naukowe Uniwersytetu Szczecińskiego, Nr 453, Ekonomiczne problemy usług, s. 145-154.

12. Mućko P., Sokół A. (2011), Jak założyć i prowadzić własnq firmę. Wydawnictwo CeDeWU, Warszawa.

13. Skrzypek T. (2009), Biznesplan. Model najlepszych praktyk. Wydawnictwo Poltext.

14. Sierpińska M., Jachna T. (2004), Ocena przedsiębiorstwa według standardów światowych. Wydawnictwo Naukowe PWN, Warszawa.

15. Stawicka M. (2009), Franczyza - droga do sukcesu. Helion, Gliwice.

16. Penc J. (2005), Sztuka Skutecznego Zarzq̨dzania, Oficyna Ekonomiczna, Kraków.

17. Raport handlowy (2015), Krajobraz centrum Warszawy. Główne ulice handlowe miasta Colliers International, listopad 2015.

18. Raport PMR 2015 (2015), Rynek HoReCa w Polsce 2015 - Prognozy rozwoju na lata 2015-2020, kwiecień.

19. Ustawa z dnia 11 marca 2004 r. o podatku od towarów i usług, art. 113 (The Act of March 11, 2004 about tax on goods and services, art. 113.)

20. Ustawa z dnia 22 lipca 2004 r. o swobodzie działalności gospodarczej, art. 22 (The Act of July 22, 2004 about the freedom of economic activity, art. 22.)

21. Wach K. (2005), Jak założyć własna firmę w Polsce. Wyd. Instytut Wspierania Przedsiębiorczości, Kraków.

22. Walczak M. (1998), Prospektywna analiza finansowa przedsiębiorstwa. PWE, Warszawa.

23. Ziółkowska K. (2016), Analiza Finansowa ex-ente jako podstawa podjęcia decyzji inwestycyjnych w sektorze usług kawiarnianych. Maszynopis SGGW Warszawa.

24. Żaro Z., Sasin P. (2005), Jak założyć i prowadzić własna firmę. Poradnik dla przedsiębiorców rozpoczynających lub kontynuujacych działalność gospodarczq według nowych przepisów prawnych. Wydawnictwo Sigma, Skierniewice. 